- Review・

\title{
Spatial and Temporal Distributions and Sources of Anthropogenic NMVOCs in the Atmosphere of China: A Review
}

\author{
Fanglin WANG ${ }^{1}$, Wei DU ${ }^{1}$, Shaojun $\mathrm{LV}^{1}$, Zhijian DING ${ }^{1}$, and Gehui WANG ${ }^{* 1,2}$ \\ ${ }^{1}$ Key Lab of Geographic Information Science of the Ministry of Education, School of Geographic Sciences, \\ East China Normal University, Shanghai 200241, China \\ ${ }^{2}$ Institute of Eco-Chongming, Shanghai 200062, China
}

(Received 15 September 2020; revised 2 January 2021; accepted 19 January 2021)

\begin{abstract}
As the key precursors of $\mathrm{O}_{3}$, anthropogenic non-methane volatile organic compounds (NMVOCs) have been studied intensively. This paper performed a meta-analysis on the spatial and temporal variations of NMVOCs, their roles in photochemical reactions, and their sources in China, based on published research. The results showed that both nonmethane hydrocarbons (NMHCs) and oxygenated VOCs (OVOCs) in China have higher mixing ratios in the eastern developed cities compared to those in the central and western areas. Alkanes are the most abundant NMHCs species in all reported sites while formaldehyde is the most abundant among the OVOCs. OVOCs have the highest mixing ratios in summer and the lowest in winter, which is opposite to NMHCs. Among all NMVOCs, the top eight species account for $50 \%-70 \%$ of the total ozone formation potential (OFP) with different compositions and contributions in different areas. In devolved regions, OFP-NMHCs are the highest in winter while OFP-OVOCs are the highest in summer. Based on positive matrix factorization (PMF) analysis, vehicle exhaust, industrial emissions, and solvent usage in China are the main sources for NMHCs. However, the emission trend analysis showed that solvent usage and industrial emissions will exceed vehicle exhaust and become the two major sources of NMVOCs in near future. Based on the meta-analysis conducted in this work, we believe that the spatio-temporal variations and oxidation mechanisms of atmospheric OVOCs, as well as generating a higher spatial resolution of emission inventories of NMVOCs represent an area for future studies on NMVOCs in China.
\end{abstract}

Key words: NMVOCs, spatial-temporal distribution, photochemical activity, source analysis

Citation: Wang, F. L., W. Du, S. J. Lv, Z. J. Ding, and G. H. Wang, 2021: Spatial and temporal distributions and sources of anthropogenic NMVOCs in the atmosphere of China: A review. Adv. Atmos. Sci., 38(7), 1085-1100, https://doi.org/10.1007/s00376-021-0317-6.

\section{Article Highlights:}

- Both NMHCs and OVOCs are more abundant in eastern developed cities than those in central and western areas.

- Among all measured NMVOCs species, OVOCs have become the second most abundant species in China.

- The top eight active NMVOCs species account for 50\%-70\% of OFP, and NMHCs have the highest OFP in winter while OVOCs have the highest OFP in summer.

- Vehicle exhaust, industrial emissions, and solvent usage are the main sources of NMVOCs.

\section{Introduction}

With the rapid economic growth, $\mathrm{O}_{3}$ shows an unexpected increasing trend in China, even though emissions of $\mathrm{NO}_{x}, \mathrm{SO}_{2}$ and $\mathrm{PM}_{2.5}$ have decreased in recent years (Sun et al., 2018b; Gaudel et al., 2018; Wang et al., 2019). Wang et al. (2019) reported that $\mathrm{O}_{3}$ has increased with a rate of 6.5 $\mu \mathrm{g} \mathrm{m}^{-3} \mathrm{yr}^{-1}$ in China during 2013-17, and significant $\mathrm{O}_{3}$ pollution is especially found in developed regions such as Jing-

\footnotetext{
* Corresponding author: Gehui WANG

Email: ghwang@geo.ecnu.edu.cn
}

Jin-Ji (JJJ, referring to the Beijing-Tianjin-Hebei area), the Yangtze River Delta region (YRD), and the Pearl River Delta region (PRD). It is well known that $\mathrm{O}_{3}$ is formed by a series of photochemical reactions, by which its concentration mainly depends on the relative levels of its photochemical precursors $\mathrm{NO}_{x}\left(\mathrm{NO}_{x}=\mathrm{NO}+\mathrm{NO}_{2}\right)$ and volatile organic compounds (VOCs) (Seinfeld and Pandis, 2006). However, compared to $\mathrm{NO}_{x}$, the roles of VOCs in the $\mathrm{O}_{3}$ formation process are more complex due to their numerous species, differential reactivities, and variable sources (Atkinson, 2000; Sahu et al., 2016; Zhang et al., 2017). Li et al. (2020) investigated the air quality changes during the 2019-20 COVID-19 
lockdown over the YRD and found that the concentrations of $\mathrm{PM}_{2.5}, \mathrm{NO}_{x}, \mathrm{SO}_{2}$, and VOCs all decreased as expected during the lockdown period, but $\mathrm{O}_{3}$ concentrations increased greatly, further suggesting the complexity of atmospheric photochemical reactions and the importance of fully understanding the connections of ozone concentration to the mixing ratios of VOCs, their sources, and their roles in the atmospheric photochemical reaction processes.

There are thousands of VOCs active in the atmosphere with parts per billion by volume to parts per trillion by volume (pptv-ppbv) levels, and most of those have atmospheric lifetimes ranging from minutes to days (Atkinson, 2000). In most cases, VOCs with a longer atmospheric lifetime evenly distribute themselves in the global atmosphere while others with a short lifetime have very strong concentration gradients in both horizontal and vertical directions due to rapid photochemical reactions (Sun et al., 2018a). Compared to those in developed countries, non-methane volatile organic compounds (NMVOCs) pollution in China is much more severe because of the high emissions from vehicular exhaust, industry, solvent usage, and biomass burning, as well as biogenic sources (Sheng et al., 2018). Previous NMVOCs studies have mainly focused on non-methane hydrocarbons (NMHCs) (Li and Wang, 2012; Wang et al., 2012; Jia et al., 2016; Sun et al., 2018b). However, a few recent studies have shown that oxygenated VOCs (OVOCs) are also an important species which affect the atmospheric oxidation capacity (Mellouki et al., 2015), among which formaldehyde, acetaldehyde, and acetone represent the three most abundant compounds, accounting for more than 70\% of the total OVOCs (Guo et al., 2016; Yang et al., 2018).

Here, we give a critical review by focusing on the analytical methods, spatiotemporal variations, photochemical characteristics, and sources of NMVOCs in urban areas to fully understand the current pollution situation of NMVOCs in China. Due to the inconsistencies in the number of species measured by different studies, this paper restricts the analysis to alkanes, alkenes, and aromatics as the representatives of NMHCs, and formaldehyde, acetaldehyde, and acetone as the representatives of OVOCs to keep the data comparable further noting that this restriction possibly led to a certain underestimate of the total NMHCs and OVOCs.

\section{Analytical methods of NMVOCs}

The analysis methods for NMVOCs can be categorized into two types, i.e., offline and online. For offline analytical methods, NMVOCs species are first collected and enriched, and then monitored by gas chromatography (GC) or high-performance liquid chromatography (HPLC) with different detectors. In GC, species are separated with a chromatographic column based on different partition coefficients with the detectability of hydrocarbons, halogenated hydrocarbons, alkyl nitrate, and BTEX (shortened form of benzene series). In HPLC, species are separated based on different partition coefficients between mobile and stationary phases under high pressure. HPLC is the preferred method for the measurement of aldehydes and ketones. The commonly used detectors include a mass spectrometer (MS), a flame ionization detector (FID), and an electron capture detector (ECD). Xue et al. (2020) analyzed NMHCs by GC-MS and carbonyl compounds by HPLC during a dust-to-haze episode in Xi' an, and finally concluded that dust might accelerate the solid-gas heterogeneous reactions of atmospheric VOCs and further induce the formation of secondary organic formation (SOA) precursors. Chen et al. (2020) quantified methane and $\mathrm{C} 2-\mathrm{C} 10$ NMHCs by GC separation followed by FID, MSD, and ECD in an oil production region in Northern China, and found that oil field emissions are dominated by alkanes while OVOCs play an essential role in the $\mathrm{RO}_{x}$ primary production, $\mathrm{OH}$ loss, and radical recycling. According to the offline results, there are large fluctuations in day-to-day concentrations for most NMVOCs, thus a long-term and continuous analytical method is necessary (Uchiyama and Hasegawa, 2000). In the 1990s, online monitoring instrumentation without preprocessing began to commercialize and has been widely used in laboratory, board, and flight monitoring applications. This advancement provided the ability to quickly capture the low concentration of tracers. The common used online monitoring instruments are proton-transfer reaction mass spectrometry (PTRMS) and the remolding of other basic online instrumentation, and the development and application methods of online instruments have been well-reviewed in previous studies (Kaser et al., 2013; Yuan et al., 2017; Dunne et al., 2018). Zhang et al. (2020a) measured NMHCs by GC-FID in Shanghai, and the results showed that the largest contribution to NMHCs are alkanes and the ratio of NMHCs to $\mathrm{NO}_{x}$ should be no less than 0.72 , to effectively control the increase of $\mathrm{O}_{3}$. Han et al. (2020) used an online system based on $\mathrm{GC}$ with a photoionization detector to conduct measurements of C6-C12 VOC species. Undoubtedly, the non-pretreatment is the largest advantage for field measurements. OVOCs are also the major source of the $\mathrm{HO}_{x}$ radicals, which are known to strongly affect the atmosphere oxidative capacity (Seinfeld and Pandis, 2006), however, large uncertainties exist (of order $30 \%-50 \%$ ) within the common measurements because of their strong dependence on relative humidity (Kaser et al., 2013). Because of this, optical instrumentation methods such as spectroscopy, including Fourier transform infrared spectroscopy (FTIR), and multiaxis differential optical absorption spectroscopy (MAXDOAS) are widely used to analyze OVOCs. Based on an FTIR analysis, Yokelson et al. (2009) reported that there have been significant increases in $\mathrm{HCHO}, \mathrm{H}_{2} \mathrm{O}_{2}, \mathrm{HCOOH}$ after biomass burning. Xing et al. (2020) measured formaldehyde and glyoxal by using MAX-DOAS to identify the sources of VOCs in wintertime in Chongqing and found that biogenic emission is the main VOCs source in the $0-100-\mathrm{m}$ layer, while anthropogenic emissions (especially biomass burning) is the dominant source in the other upper layers. Above all, in recent years, online instruments are increas- 
ingly becoming popular in NMVOCs observations due to their advantages regarding high time resolution, instantaneous data availability, and non-pretreatment.

\section{Spatial and temporal distribution}

\subsection{Spatial distribution}

Figure 1a shows the spatial distribution of urban NMHCs in China based on an entire year of data. The mixing ratio of total NMHCs ranged from 24.32 ppbv to 43.16 ppbv, with the lowest values observed in the background cities, like Lhasa (Lhasa, 14.12 ppbv), and the highest concentrations observed in the northwest, northeast, and developed areas such as JJJ, YRD, and PRD. Among all the NMHCs, alkanes are the dominant species across the country. Also, concentrations of aromatic hydrocarbons are observed to be relatively higher in the developed areas. NMHCs are mainly derived from vehicle exhaust, industrial emissions, coal/fuel combustion, fuel volatilization, biomass burning, and solvent usage in urban areas (Zhang et al., 2013; Zheng et al., 2013; Wang et al., 2014). The higher NMHCs in the northwest and northeast regions of China are most likely caused by coal combustion for residential heating.

As shown in Fig. 1b, the annual mixing ratio of the total OVOCs in the urban areas of China ranged from 8.36 ppbv to $24.75 \mathrm{ppbv}$, which is about one to four times of that observed in urban downwind regions such as Dinghushan (6.99 ppbv), which is a background site of Guangzhou City. Being similar to that of NMHCs, the spatial distribution of OVOCs in China also showed higher concentrations in the developed metropolitan clusters such as JJJ, YRD, and PRD regions. Formaldehyde is the most abundant OVOC, followed by acetaldehyde in the three developed areas, while acetone is the largest species in northeastern and central China. OVOCs are primarily emitted from industry, traffic exhaust, solvent usage, coal combustion, and biogenic sources, with photochemical reactions acting as a secondary source (Chen et al., 2014). Lyu et al. (2020) performed a source apportionment of ambient formaldehyde and acetaldehyde in China, the results showed that secondary formation is the main source of formaldehyde in most cities of China. However, the sources of acetaldehyde are quite complex, of which the main sources are secondary formation in PRD and central China, the aged air masses in JJJ, and vehicle exhausts in northeast China. Recently, some new OVOCs such as formic acid and acetic acid have been measured by field observations due to the improvement of detection capability. According to previous studies, the concentration of formic acid is around $3 \mathrm{ppbv}$ and the concentration of acetic acid ranges from 0.7 to $3.5 \mathrm{ppbv}$, in the autumn-winter period of China (Yuan et al., 2012; Louie et al., 2013; Ho et al., 2014; Sheng et al., 2018). A few studies reported that concentrations of OVOCs have exceeded that of aromatics and
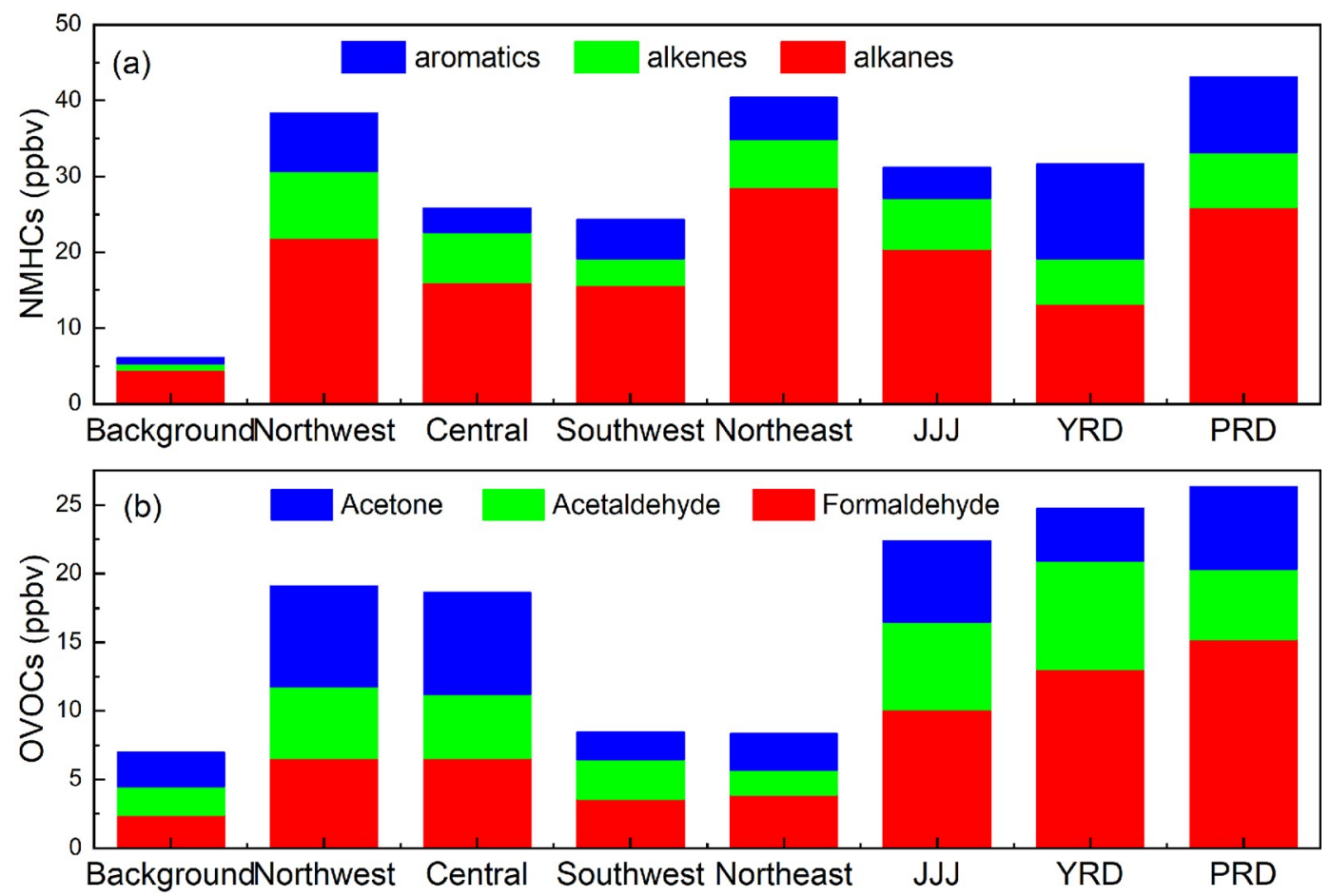

Fig. 1. The spatial distribution of NMHCs and OVOCs in background regions of Lhasa (Zhang, 2016), and Dinghushan (Chi et al., 2008), northwest urban areas [Lanzhou (Jia et al., 2016), Xi'an (Ho et al., 2014)], central [Wuhan (Yang et al., 2019b)], southeast [Chongqing, Guiyang (Pang and Lee, 2010)], northeast [Shenyang (Ma et al., 2019)], and developed regions [Shanghai (Huang et al., 2008), Beijing (Pang and Mu, 2006; Sheng et al., 2018), Guangzhou (Zou et al., 2015)] (Except for the background points for comparison, the statistics all were based on whole year observations from the relevant references). 
have become the second contributor to NMVOCs in some cities of China (Yuan et al., 2012; Deng et al., 2019; Mozaffar et al., 2020).

\subsection{Temporal variations}

Figure 2 shows the annual variations of NMHCs after 2007, in urban Shanghai and Beijing. In Shanghai, the mixing ratio of NMHCs ranged from 8.91 to $74.27 \mathrm{ppbv}$ from 2007 to 2015 and decreased by $26.1 \%$ in 2014 compared to that in 2007. Specifically, alkanes, alkenes, and aromatics all have decreased. In 2010, the average concentration of NMHCs in Shanghai was 26.45 ppbv, representing a decrease of $37.87 \%$ relative to May 2019 (Wang, 2020). Wang et al. reported that concentrations of NMHCs in Beijing increased at first due to the abrupt increase in the number of vehicles in 2000-03, and began to decrease in 2004 due to the implementation of policies concerning gasoline emission and air pollution controls (Wang et al., 2012). Wang et al. (2015) further found that the concentrations of NMHCs have continuously decreased, specifically noting a reduction of $37 \%$ in 2013 compared to that in 2007, as shown in Fig. 2. An abrupt decrease of NMHCs in 2018 in Beijing can be attributed to the 2008 Olympic Games, during which time, the Chinese government enacted very strict emission controls. A similar decreasing trend was also observed in other cities of China. For example, NMHCs exhibited a slight decrease during 2005-15 in Hong Kong (Wang et al., 2017b), and decreased by $28.8 \%$ during 2006-08 in Guangzhou (Yuan et al., 2012).

Figure 3 shows the seasonal variations of NMHCs in central (Wuhan)-western (Lanzhou or Xi'an) China and the developed regions (Beijing, Shanghai, Guangzhou). It can be seen that NMHCs concentrations are higher in winter

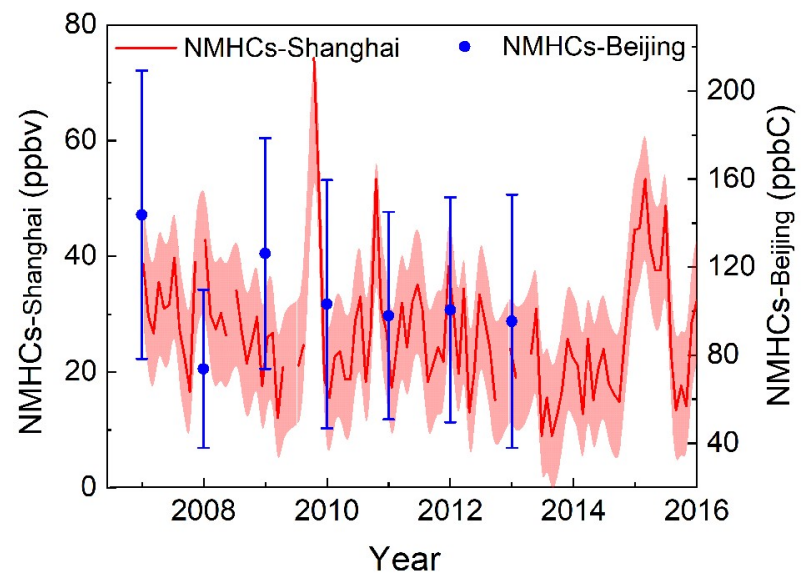

Fig. 2. Annual variations of NMHCs in urban Shanghai (Gao et al., 2017; Xu et al., 2019) and Beijing (Wang et al., 2015).

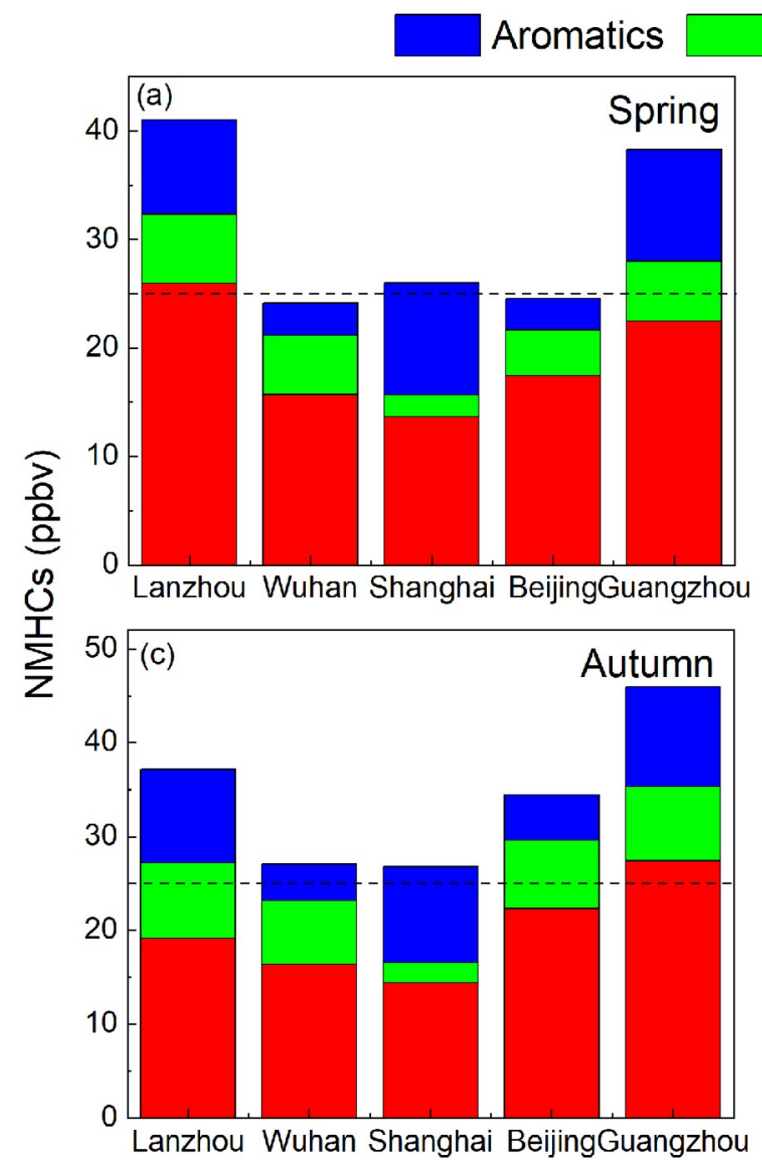

Alkenes Alkanes

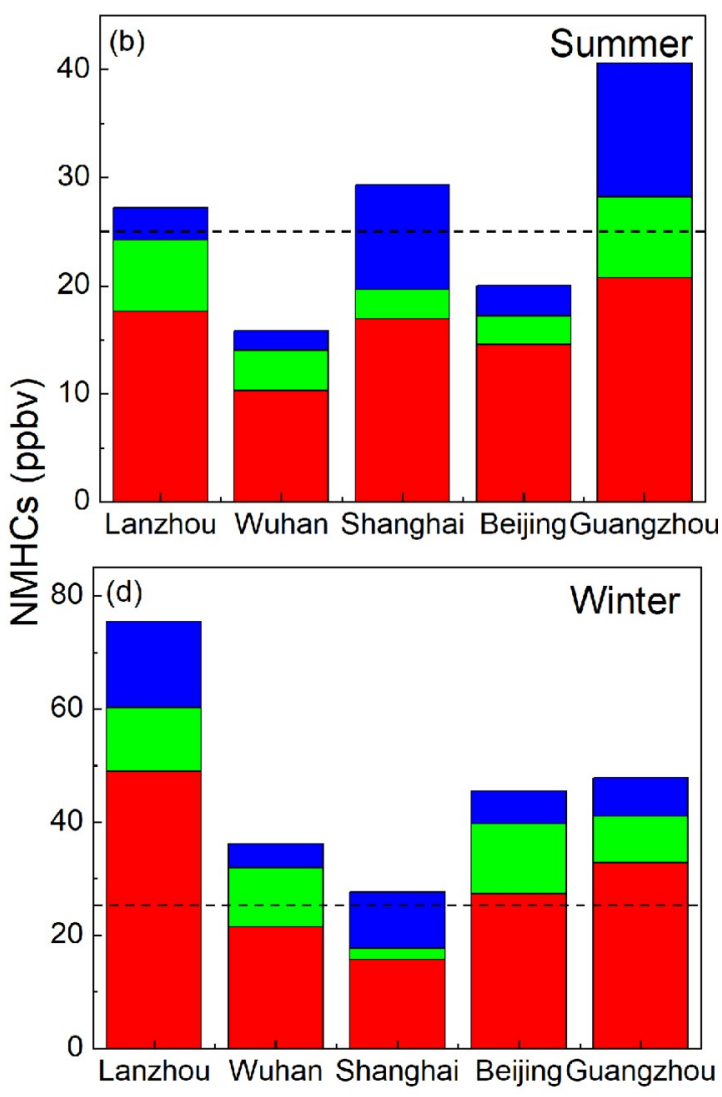

Fig. 3. Seasonal variations of NMHCs in the urban atmosphere of Lanzhou (Jia, 2018), Wuhan (Yang et al., 2019a), Shanghai (Su, 2012), Beijing (Zhang et al., 2020b), Guangzhou (Zou et al., 2015). The dashed lines represent the total mixing ratio equal to $25 \mathrm{ppbv}$. 
and autumn and lower in spring and summer, with average mixing ratios of $26.48-75.43 \mathrm{ppbv}$ in winter, 25.28-45.97 ppbv in autumn, 20.68-41.00 ppbv in spring, and 15.84-40.58 ppbv in summer, respectively. In all seasons, alkanes are the dominant species for all sites. The higher concentrations of NMHCs observed in winter and autumn might be caused by differential sources and meteorological factors (e.g., stagnant conditions and lower temperatures). As seen in Fig. 3, the seasonal variations in the southern part of China (20.60-26.48 ppbv in Shanghai and 38.25-47.84 ppbv in Guangzhou) are not as obvious as those in the northern part (41.00-75.43 ppbv in Lanzhou and 24.55-45.54 ppbv in Beijing). The higher concentrations of NMHCs in the northern cities during the cold seasons are believed to be a consequence of enhanced residential heating emissions.

Figure 4 shows that the mixing ratios of OVOCs are highest in summer (13.30-42.00 ppbv) and lower in winter (10.22-18.57 ppbv) for the developed regions of China. Pang and $\mathrm{Mu}$ (2006) found that OVOCs correlated well with $\mathrm{O}_{3}$ in summer, but with $\mathrm{CO}$ in winter, indicating that the sources are dominated by photo-oxidation in summer as opposed to vehicular exhaust in winter. Liu et al. (2009) also reported that in Beijing, secondary formation (48\%) is the largest source of acetaldehyde in summer. In western
(Xi' an) and central (Wuhan) cities, slightly higher concentrations of OVOCs were observed in winter, although the mechanisms that might serve to explain the seasonal variation were not so obvious, with mixing ratios fluctuating around $10 \mathrm{ppbv}$. Such an insignificant seasonality indicated that the primary emissions of OVOCs in Xi' an and Wuhan may dominate over the secondary formation.

Figure 5 shows the diurnal variations of NMHCs $(a-c)$ and OVOCs (d-e). It can be seen that alkanes, alkenes, and aromatics all showed higher mixing ratios in the morning and the afternoon, respectively. NMHCs react with $\mathrm{OH}$ radicals, $\mathrm{Cl}$ radicals, and $\mathrm{O}_{3}$ during daytime and with $\mathrm{NO}_{3}$ radicals during nighttime (Le Breton et al., 2018). The reaction rate with $\mathrm{NO}_{3}$ radicals is much lower than that with $\mathrm{OH}$ radicals, which is in part responsible for the lower concentrations of NMHCs observed during daytime (Xu et al., 2017). The higher concentrations in the morning are probably caused by an increase in vehicle exhaust emissions during the morning rush hours. As shown in Figs. 5d-e, the diurnal variations pattern of OVOCs is opposite to that of NMHCs, which shows higher concentrations during daytime with maxima around local noon, suggesting the importance of daytime secondary formation (Yuan et al., 2012). Additionally, some OVOCs also displayed a small peak in the evening, which is probably caused by the local primary emissions.
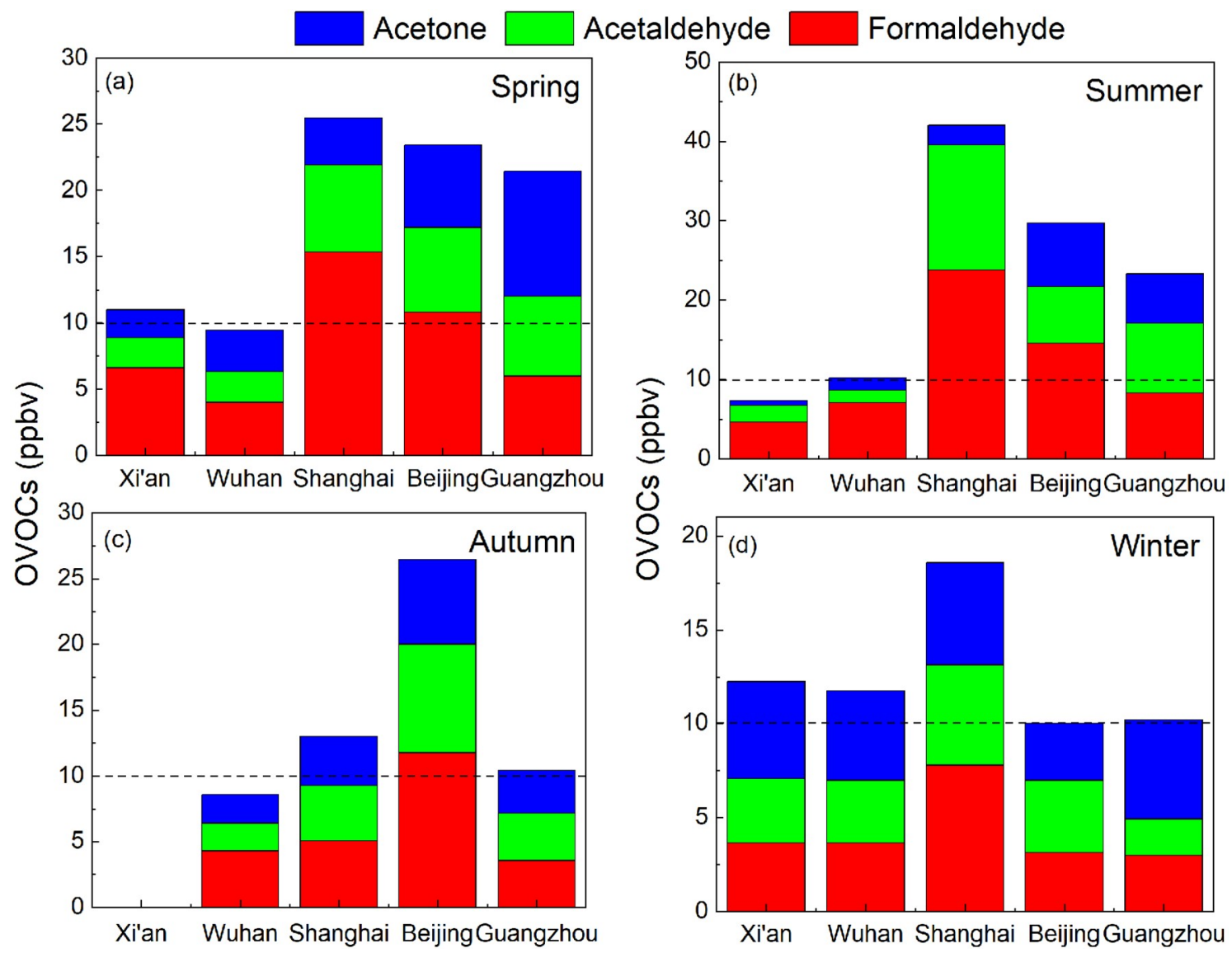

Fig. 4. Seasonal variations of OVOCs in the urban atmospheres of Xi'an (Ho et al., 2014), Wuhan (Yang et al., 2019a), Shanghai (Huang et al., 2008), Beijing (Pang and Mu, 2006), and Guangzhou (Lü et al., 2010). The dashed lines represent the total mixing ratio equal to $10 \mathrm{ppbv}$. 

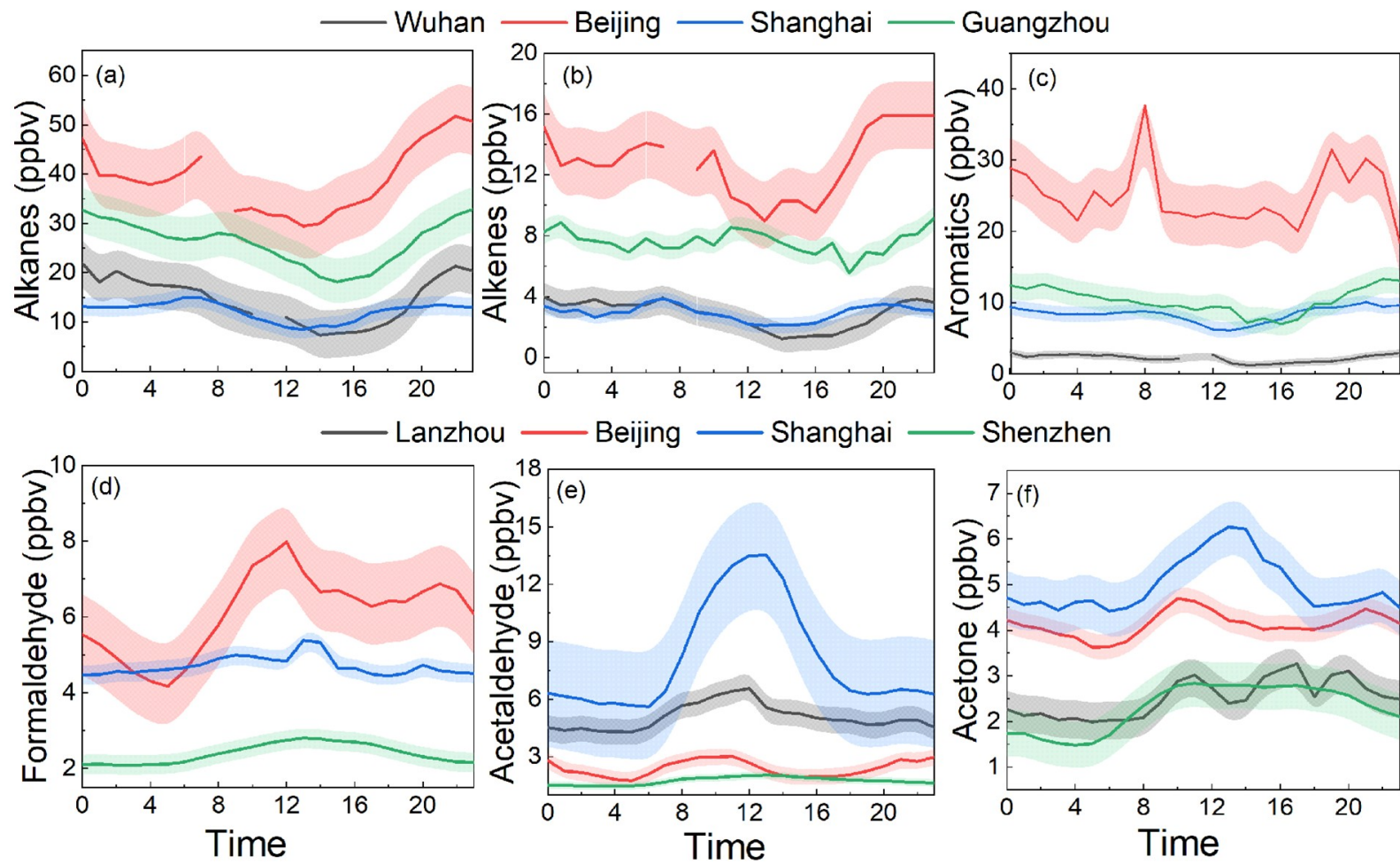

Fig. 5. Diurnal variations of alkanes (a), alkenes (b), and aromatics (c) in urban Wuhan (Hui et al., 2020), Shanghai (Su, 2012), Beijing (Zhang et al., 2020b), Guangzhou (Zou et al., 2015) and formaldehyde (d), acetaldehyde (e), and acetone (f) in Lanzhou (Zhou et al., 2019), Beijing (Liu et al., 2015b), Shanghai (unpublished data from this study), and Shenzhen (Huang et al., 2020).

Undoubtedly, some meteorological factors such as boundary layer height and wind speed also affect the diurnal variation patterns of NMVOCs.

\section{Photochemical characteristics}

\subsection{Roles in the photochemical reactions}

Theoretically, VOCs can react with $\mathrm{NO}_{x}$ in the presence of solar radiation (be represented by " $h v$ "), ultimately producing ozone and other oxidants (collectively referred as " $M$ ") such as aldehyde, peroxyacetylnitrate (PAN), $\mathrm{H}_{2} \mathrm{O}_{2}$, etc. (Liu et al., 1987; Warneke et al., 1999; Tang et al., 2006).

$$
\mathrm{VOCs}+\mathrm{NO}_{x}+h v \rightarrow \mathrm{O}_{3}+M .
$$

The process of atmospheric photochemical reactions is very complex, which can be roughly classified into four stages, i.e., initiation reaction, radical formation, radical chain transfer, or termination reaction (Wang et al., 2017a; Jia, 2018). They can be further categorized into the " $\mathrm{NO}_{x}$ cycle" and " $\mathrm{RO}_{x}$ cycle", as shown in Fig. 6. The photochemical reactions within the $\mathrm{NO}_{x}$ cycle, differ for two background situations, i.e., clean and polluted conditions. In clean air, $\mathrm{O}\left({ }^{3} \mathrm{P}\right)$ (oxygen atoms) can be produced through the photolysis of $\mathrm{NO}_{2}$ by wavelengths under $424 \mathrm{~nm}$, which then proceed to react further with $\mathrm{O}_{2}$ to produce $\mathrm{O}_{3}$. Once $\mathrm{O}_{3}$ is formed, it can oxidize $\mathrm{NO}$ to $\mathrm{NO}_{2}$ [Eq. (2) -Eq. (4)].
However, this cycle quickly reaches a photochemical stable state, and thus there is no net formation of $\mathrm{O}_{3}$ and no accumulation in the atmosphere. In polluted air, many radicals exist, like $\mathrm{OH}$ and $\mathrm{HO}_{2}$, which are products of the photochemical reactions of VOCs. After a series of $\mathrm{OH}$ radical transfer reactions, many peroxy-radicals are generated such as $\mathrm{HO}_{2}$ and $\mathrm{RO}_{2}$. These peroxy-radicals can suppress and replace $\mathrm{O}_{3}$ oxidation of $\mathrm{NO}$ [Eq. (5)-Eq. (6)] due to their stronger oxidizing capacity, the generated $\mathrm{NO}_{2}$ can further participate in the "NO$x$ cycle" [Eq. (2)-Eq. (4)], resulting in the accumulation of $\mathrm{O}_{3}$ in the polluted atmosphere.

$$
\begin{gathered}
\mathrm{NO}_{2}+h v \rightarrow \mathrm{O}\left({ }^{3} \mathrm{P}\right)+\mathrm{NO}, \\
\mathrm{O}\left({ }^{3} \mathrm{P}\right)+\mathrm{O}_{2} \rightarrow \mathrm{O}_{3}, \\
\mathrm{O}_{3}+\mathrm{NO} \rightarrow \mathrm{O}_{2}+\mathrm{NO}_{2}, \\
\mathrm{HO}_{2}+\mathrm{NO} \rightarrow \mathrm{OH}+\mathrm{NO}_{2}, \\
\mathrm{RO}_{2}+\mathrm{NO} \rightarrow \mathrm{RO}+\mathrm{NO}_{2} .
\end{gathered}
$$

The " $\mathrm{RO}_{x}$ cycle", is usually started by the formation of $\mathrm{OH}$, and then forms a radical cycle as " $\mathrm{OH} \rightarrow \mathrm{RO}_{2} \rightarrow \mathrm{RO} \rightarrow$ $\mathrm{HO}_{2} \rightarrow \mathrm{OH}$ " as illustrated in Fig. 6. The sources of $\mathrm{OH}$ are mainly dependent on the photolysis of $\mathrm{HONO}, \mathrm{O}_{3}$, and the reactions of $\mathrm{O}_{3}$ with alkenes (Volkamer et al., 2010; Young 


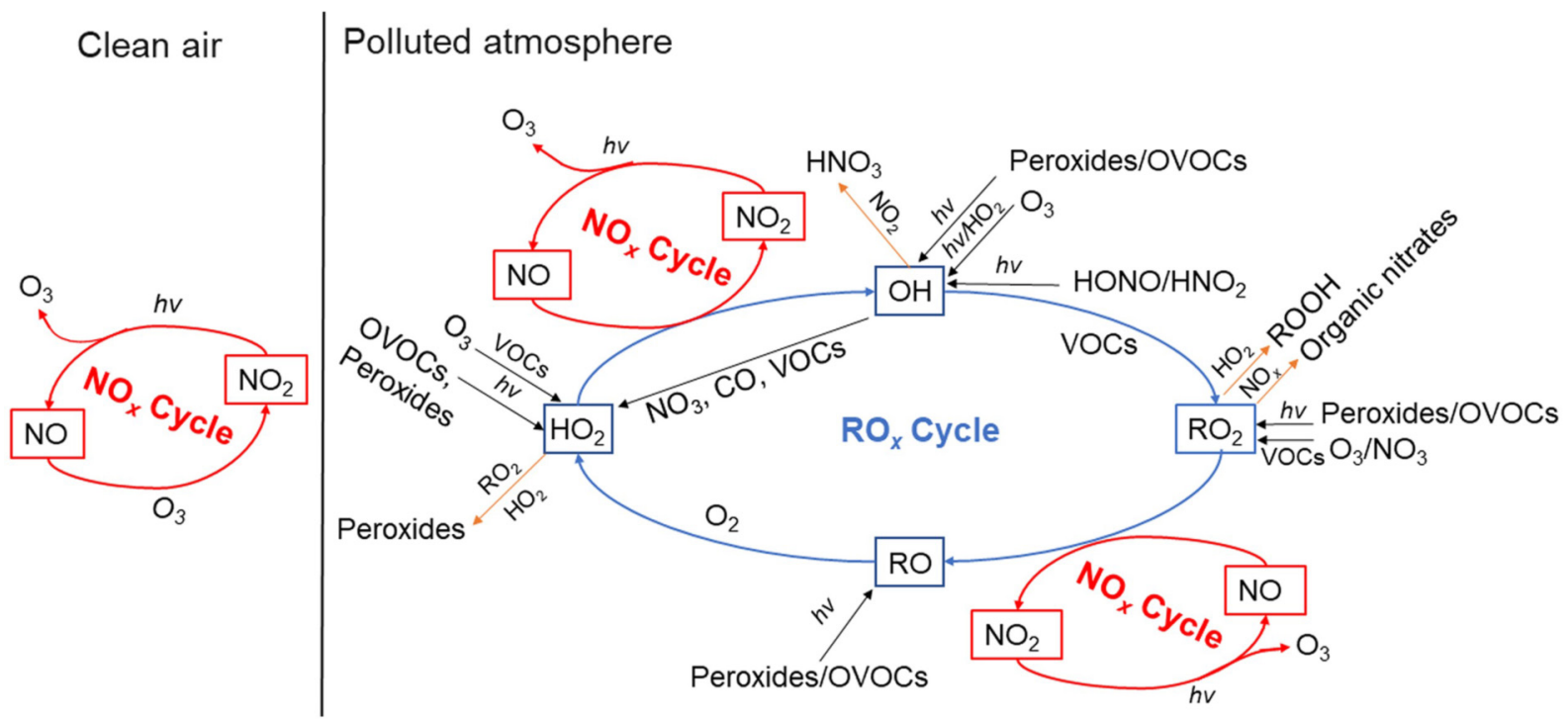

Fig. 6. A schematic plot for the mechanism of ozone formation in " $\mathrm{NO}_{x}$ cycle" and " $\mathrm{RO}_{x}$ cycle" (the red lines represent initiation reactions, the black lines represent radical formation reactions, the blue lines represent radical transfer reactions, and the yellow lines represent termination reactions).

et al., 2012). These different sources produce $\mathrm{OH}$ radicals at different times during the day. In the early morning (0600-0900 LST) (local standard time, hereafter), photolysis of HONO is the dominant source of $\mathrm{OH}$ radicals (Wang et al., 2016a; Ge et al., 2019), but a few hours later the photolysis of $\mathrm{O}_{3}$ becomes the dominant source and peaks at midday. The reaction of $\mathrm{O}_{3}$ with alkenes is a gasphase non-photolytic source of $\mathrm{OH}$ that takes place during the entire day and also peaks at midday, like photolysis of $\mathrm{O}_{3}$. Additionally, the reaction of $\mathrm{O}_{3}$ with alkenes represents another important source of $\mathrm{OH}$ radicals in the early morning, under lower $\mathrm{O}_{3}$ and higher alkene conditions. Among the different $\mathrm{OH}$ sources, HONO photolysis production is the fastest (Hang et al., 2008). Except for the sources from the radical transfer reactions in the $\mathrm{RO}_{x}$ cycle, the photolysis of HCHO and secondary OVOCs are also primary sources of daytime $\mathrm{HO}_{2}$ radicals, while the reactions of $\mathrm{O}_{3}$ with alkenes are the main sources in the nighttime (Shirley et al., 2006), further noting that the daytime photolysis of formaldehyde accounts for more than half of the $\mathrm{HO}_{2}$ radicals.

$\mathrm{RO}_{2}$ is mainly derived from the photolysis of OVOCs, the reactions of $\mathrm{O}_{3}$ with alkenes, the reactions of $\mathrm{NO}_{3}$ with alkenes, $\mathrm{CO}$ and VOCs, and $\mathrm{OH}$-radical initiated oxidations of aromatics (Xue et al., 2016). The diurnal variation of $\mathrm{RO}_{2}$ radical production is similar to that of $\mathrm{HO}_{2}$ radical. In each $\mathrm{RO}_{x}$ cycle, two molecules of $\mathrm{NO}$ are oxidized to $\mathrm{NO}_{2}$, which then goes on to generate two molecules of $\mathrm{O}_{3}$, eventually leading to the accumulation of $\mathrm{O}_{3}$. The $\mathrm{NO}_{x}$ cycle and $\mathrm{RO}_{x}$ cycle begin to terminate when the free radicals accumulate and achieve higher concentrations through the cross-reactions of $\mathrm{RO}_{x}$ and the reactions between $\mathrm{RO}_{x}$ and $\mathrm{NO}_{x}$ (Whalley et al., 2009). In the areas with high $\mathrm{NO}_{x}$ concentrations, the cycles are terminated by the reactions of $\mathrm{NO}_{2}$ with $\mathrm{OH}$ and $\mathrm{RO}_{2}$, with the terminal products being nitric acid and organic nitrates. While in the areas with low $\mathrm{NO}_{x}$, the termination reactions are dominated by the self-reactions of $\mathrm{HO}_{2}$ and the cross-reactions of $\mathrm{HO}_{2}$ and $\mathrm{RO}_{2}$, ultimately yielding peroxides $\left(\mathrm{H}_{2} \mathrm{O}_{2}\right.$ and $\left.\mathrm{ROOH}\right)$.

Due to the complexity of photochemical reactions and diversity of VOC species, the complete details which explain the $\mathrm{O}_{3}$ formation mechanism and probable sources of $\mathrm{RO}_{x}$ are still under exploration. It was reported that $\mathrm{ClNO}_{2}$ can affect $\mathrm{O}_{3}$ formation through the reactions [Eq. (7)-Eq. (9)] by the formation of $\mathrm{RO}_{2}$ (Thornton et al., 2010; Riedel et al., 2014). Recent studies showed that $\mathrm{CINO}_{2}$ levels ranged from 0.35 to $4.7 \mathrm{ppbv}$ in the atmosphere, which can contribute to $10 \%-30 \%$ of $\mathrm{RO}_{x}$ in the morning and enhance the integrated daytime $\mathrm{O}_{3}$ production by up to $11 \%-41 \%$ at a mountain site in Hong Kong and to 4.3 ppbv on average in the rural of North China Plain (Tham et al., 2016; Wang et al., 2016b). Young et al. (2012) found that radical production from HONO mainly occurs in the period of 0600-0900 LST and decreases at higher planetary boundary layer (PBL) heights, while the radicals produced from $\mathrm{ClNO}_{2}$ mainly occur in the time of 0600-1200 LST with no significant dependence on the PBL height. Their contributions to $\mathrm{OH}$ are comparable near the ground surface, but the fraction of $\mathrm{ClNO}_{2}$ contributing to $\mathrm{OH}$ radicals is higher at higher PBL heights. However, due to the inherent complexity, which species and processes dominate the nighttime $\mathrm{OH}$ radical production and whether or not $\mathrm{O}_{3}$ or $\mathrm{NO}_{3}$ affect or control its formation are still under exploration (Volkamer et al., 2010).

$$
\begin{gathered}
\mathrm{N}_{2} \mathrm{O}_{5}+\mathrm{Cl}^{-} \rightarrow \mathrm{ClNO}_{2}+\mathrm{NO}_{3}^{-}, \\
\mathrm{ClNO}_{2}+h v \rightarrow \mathrm{Cl}+\mathrm{NO}_{2},
\end{gathered}
$$




$$
\mathrm{RH}+\mathrm{Cl}+\mathrm{O}_{2} \rightarrow \mathrm{RO}_{2}+\mathrm{HCl} .
$$

\subsection{Key photochemical activity}

As the differences in structures, concentrations, and chemical reaction rates present themselves, the chemical activities of different VOC species change, resulting in differing contributions to $\mathrm{O}_{3}$ production. As discussed above, VOCs play a key and complex role in the $\mathrm{O}_{3}$ formation process, hence it is essential to find out which species are the key components that affect the atmospheric oxidizing capacity. In general, the photochemical reaction activity order of NMVOC is as follows: inner double alkene $>$ alkyl or trialkyl aromatic hydrocarbon and outer double alkene $>$ ethene $>$ monoalkyl aromatic hydrocarbon $>\mathrm{C} 5$ and C8 alkanes $>$ C2-C5 alkane (Tang et al., 2006). The most common recognition methods are ozone formation potential (OFP) and $\mathrm{OH}$ consumption rate $\left(L_{\mathrm{OH}}\right)$ (Duan et al., 2008). Studies about OFP and $L_{\mathrm{OH}}$ showed that alkenes, aromatic hydrocarbons, and OVOCs are key reactive species, although there are some slight differences in different areas, seasons, and pollu- tion events (Li and Wang, 2012; An et al., 2015; Zhu et al., 2020). For example, in Shenyang, a megacity in northeast China, the top three contributors to OFP are aromatics (31.2\%), alkenes (25.7\%), and OVOCs (25.6\%) (Ma et al., 2019). In contrast, OVOCs in Guangzhou city, south China are the largest contributors of OFP (34.0\%-50.8\%) (Yuan et al., 2012), while alkenes $(48.34 \%)$ are the main contributors in Wuhan, central China (Hui et al., 2020).

The top ten reactive species in China are $m / p$-xylene, ethylene, formaldehyde, toluene, propene, acetaldehyde, $o$ xylene, styrene, 1,3-butadiene, and 1,2,4-trimethylbenzene (Wu and Xie, 2017). As shown in Fig. 7, their contributions to the total OFP are different in different areas (Duan et al., 2008; Deng et al., 2019; Fu et al., 2020; Zhao et al., 2020; Zhou et al., 2020; Zhu et al., 2020). Contributions of the top eight NMVOCs to OFP account for 51\%-69\% of the total, among which OVOCs, especially formaldehyde and acetaldehyde, contribute more to OFP in megacities. The main areas in China with high OFP, expand regionally from Jiangsu Province to four regions including the North China Plain,
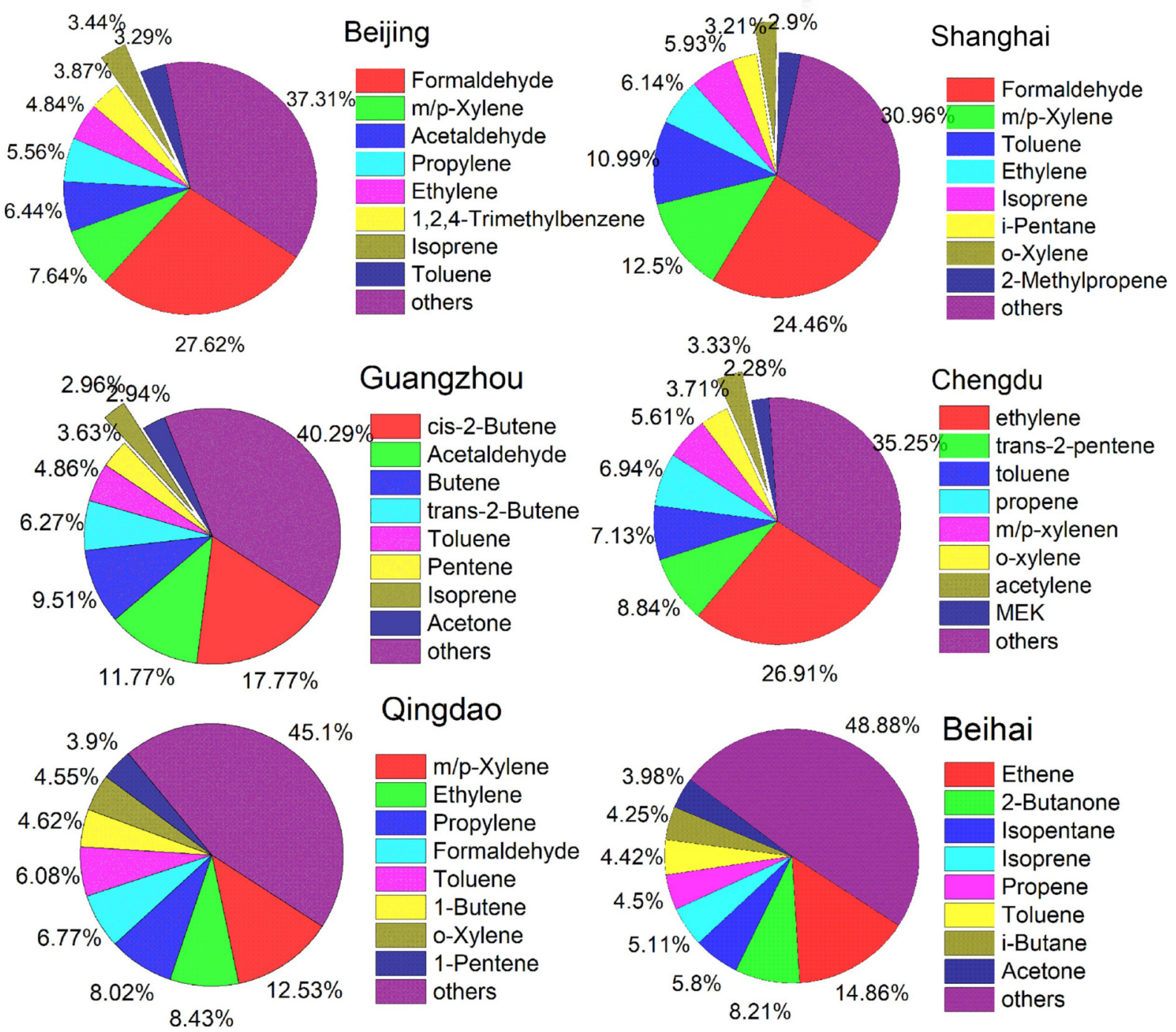

Fig. 7. The contributions of the top eight NMVOCs to OFP in different cities of China. 
YRD, PRD, and the Sichuan Basin due to the rapid growth of the economy and the fast expansion of urbanization (Li et al., 2019b). Figure 8 shows the seasonal variations of OFP produced by NMHCs and OVOCs. As seen in Fig. 8, the seasonal variations are different with the highest OFP-NMHCs appearing in winter and the highest OFP-OVOCs occurring in summer. The OFPs in China are higher in developed regions than that in the northwestern and central areas, and these two categories contribute almost equally to the total OFP. Except for the primary emissions, the highest OFPOVOCs in summer are mainly attributed to photochemical reactions, and the highest OFP-NMHCs in winter can be attributed to both unfavorable meteorological conditions

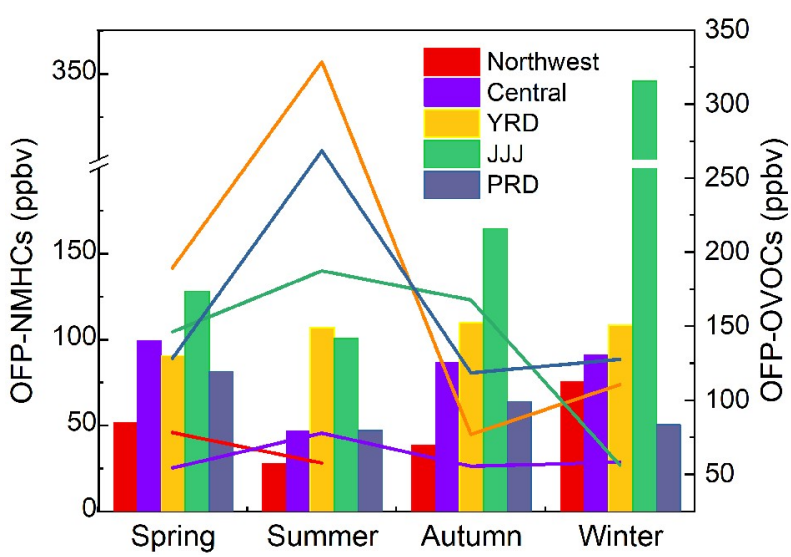

Fig. 8. Seasonal variations of OFP-NMHCs (bar graph) and OFP-OVOCs (line chart) in different cities of China (The data given here are recalculated from the references cited in section $3.2)$. and enhanced residential heating emissions. Only a few studies have focused on the diurnal variations of $L_{\mathrm{OH}}$, which tend to show that $L_{\mathrm{OH}}$ achieves the highest values in the morning and the lowest values around noon and that short-chain alkenes are dominant for morning $L_{\mathrm{OH}}$ while long alkenes dominate the noon $L_{\mathrm{OH}}$, however, the diurnal variation of $L_{\mathrm{OH}}$ produced by OVOCs is not obvious (Xu et al., 2017).

\section{Sources of NMVOCs}

The main methods to determine the sources of pollutants are emission analysis, trend analysis, tracer studies, trajectory analysis, receptor models, and diffusion models (Blanchard, 2003). Currently, the most commonly used methods to determine the sources of NMVOCs fall into two main categories: (1) receptor models which are supplemented with the use of tracer methods, of which the most widely used receptor models are the chemical mass balance method (CMB), principal component analysis (PCA) and positive matrix factorization (PMF); (2) emission and trend analysis.

\subsection{Receptor models}

Figure 9 shows the source appointment of NMHCs based on PMF analysis. Six sources including vehicle exhaust, solvent usage, industrial emissions, fuel evaporation, liquefied petroleum gas (LPG) usage, and combustion are found to be the major sources of NMHCs in China. However, the relative contributions from each source within the various regions differ. In the Karamay of Xinjiang, coal combustion is the biggest contributor to the local NMHCs, followed by industrial emissions and oil volatilization (Zhang
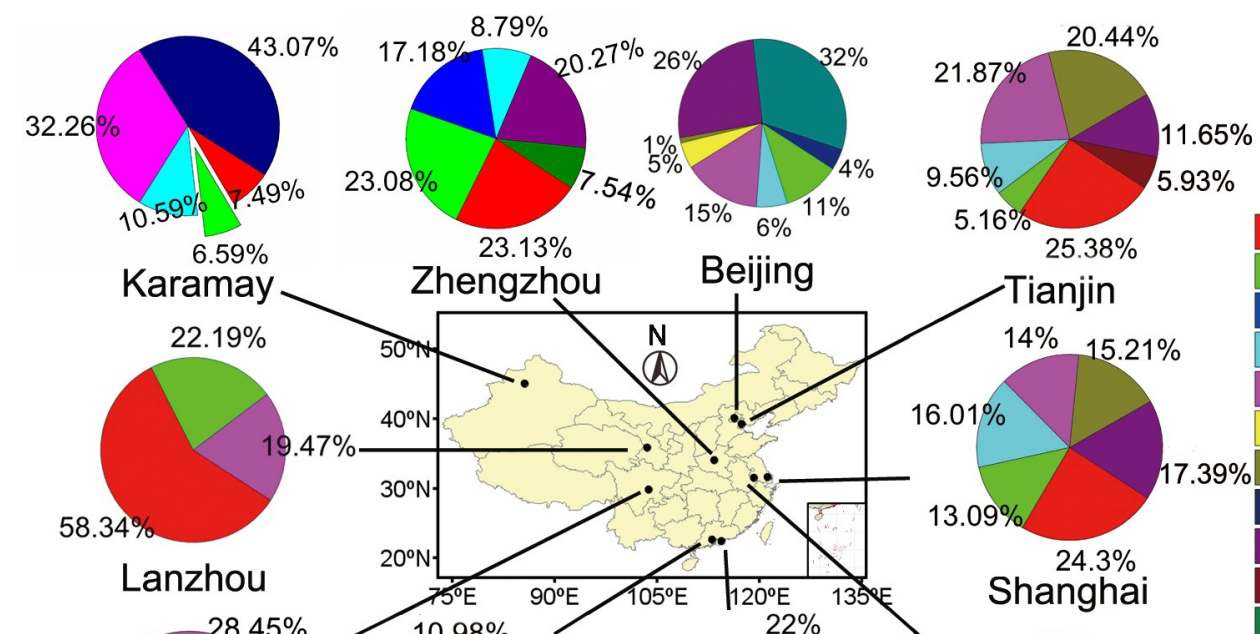
Solvent use Biogenic Fuel evaporation Industrial Biomass burning LPG usage Coal burning Cmbustion

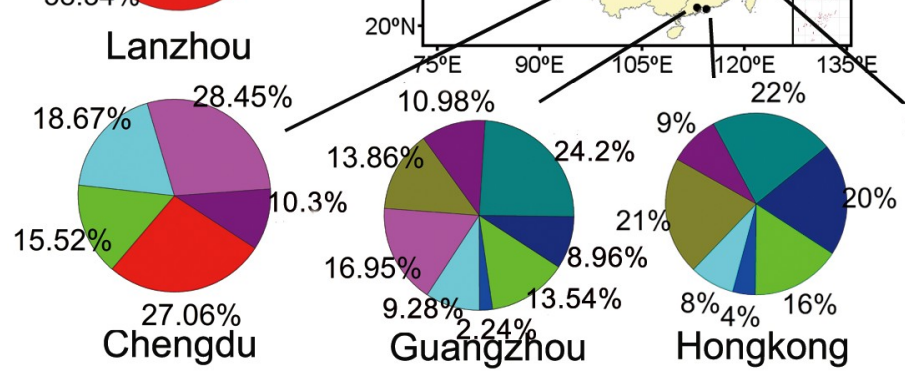

Shanghai Pertrochemical Gasoline exhaust

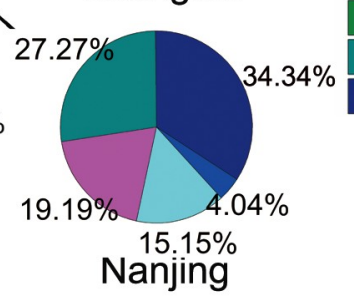
Diesel exhaust Others

Fig. 9. Atmospheric NMHCs sources in the urban atmosphere of China. The data obtained from the following references (Cai et al., 2010; Yuan et al., 2013; Ling and Guo, 2014; Li et al., 2015; Jia et al., 2016; Liu et al., 2016; Wu et al., 2016b; He, 2018; Li et al., 2019a; Zhang et al., 2019). 
et al., 2019). In the developed cities (Beijing, Guangzhou, and Hong Kong), vehicle exhaust is the largest source, further noting that the contribution from gasoline exhaust is much more significant than that from diesel exhaust. In Beijing and Tianjin industrial emission is the second largest contributor of NMHCs, while in Shanghai and Nanjing, two megacities of the YRD, vehicle exhaust, industrial emissions, and fuel evaporation are the three major sources for NMHCs. In the PRD cities like Guangzhou and Hong Kong, LPG usage and solvent usage are the two main contributors to NMHCs, exceeded only by vehicle exhaust. For the megacities in Sichuan Basin such as Chengdu, vehicle exhaust, industrial emissions, fuel evaporation, and solvent usage all contribute significantly to NMHCs. In Hong Kong, Guo et al. (2006) found that $43 \%$ of NMHCs in the local atmosphere were derived from industrial emissions with an additional 39\% of NMHCs transported in from the neighboring PRD region. Sources of NMHCs exhibit significant differences not only spatially, but also temporally. For example, Wu et al. (2016b) reported that in the city limits of Beijing, the wintertime of gasoline exhaust increased by 1.4 times in a haze event compared with what was observed during a non-haze period. In Dushanzi, a district of Xinjiang, during a non-heating period, coal combustion contributed $25.3 \%$ to NMHCs, but increased to $43.3 \%$ during a heating period in cold season, while the contribution of oil volatilization dramatically increased during a sandstorm event (Zhang et al., 2019).

Table 1 lists the sources of OVOCs based on a parameterization method. It can be seen that secondary formation and biogenic emission are the two largest sources for formaldehyde, acetaldehyde, and acetone in both Beijing and Shenzhen during summer, however, acetone have a high regional background level (Yuan et al., 2013; Huang et al., 2020). Secondary formation is important for formic acid and acetic acid in Changdao Island during spring, even though primary emission is the largest source for acetic acid (Yuan et al., 2013). A source appointment study on carbonyl carried out by Chen et al. based on PMF analysis (Chen et al., 2014) showed that secondary formation, traffic-related emissions, industry emissions, solvent usage, and coal burning are the main sources of OVOCs in winter. However, in summer the main sources of OVOCs are secondary formation, trafficrelated emissions, industry emissions, solvent usage, and biogenic sources. Notably, the source of secondary formation contributes to nearly half to all OVOCs in both summer and winter.

\subsection{Emission and trend analysis}

With the rapid growth of the economy in China in the past decades, anthropogenic NMVOCs emissions have continuously been increasing. Wu et al. (2016a) reported that the TVOCs (total VOC) emissions in China had increased by $7.38 \%$ per year over 2008-12. Sun et al. (2018b) further reported that the annual growth rate of NMVOCs in China was 4.6\% from 1949-2015, while Li et al. (2019c) found that the anthropogenic NMVOCs emissions increased by $65.8 \%$ over 1990-2017. Since 2013, Shandong, Jiangsu, and Guangdong Provinces have evolved into the three major regions that are making higher contributions to the total NMVOCs emissions in China, and have been classified as the worst- affected areas of NMVOCs pollution (Bo et al., 2008; Wei et al., 2008; Zheng et al., 2017). Although the total amount of NMVOCs emissions in China during 1990-2017 had continuously increased, the growth rate has significantly decreased after the implementation of strict reduction measures in 2015 .

The NMVOCs emission source inventory generally includes residential, transportation, industry, solvent use, and power plants. For each specific source, there exist some differences in patterns related to the emissions. The emissions and growth rates of residential NMVOCs have been decreasing ( $\mathrm{Li}$ et al., 2019c), which mainly due to the energy type conversion in households (Du et al., 2018). Transportation mainly includes road gasoline and both road and non-road diesel. The growth rate of transportation shows a sharp increase from 1990 to 2008 followed by a gradual decrease ( $\mathrm{Li}$ et al., 2019c). The increase in transportation emissions is mainly caused by the increase in the number of cars around 2008, while the latter decrease is mainly attrib-

Table 1. The source appointment of OVOCs.

\begin{tabular}{|c|c|c|c|c|c|c|}
\hline & $\begin{array}{l}\text { OVOCs } \\
\text { species }\end{array}$ & $\begin{array}{c}\text { Primary } \\
\text { emission }(\%)\end{array}$ & $\begin{array}{c}\text { Secondary } \\
\text { formation }(\%)\end{array}$ & Biogenic (\%) & Background (\%) & References \\
\hline \multirow[t]{4}{*}{ Beijing } & & & & & & (Huang et al., 2020) \\
\hline & Formaldehyde & 22 & 28 & 36 & 15 & \\
\hline & Acetaldehyde & 16 & 48 & 13 & 22 & \\
\hline & Acetone & 30 & 9 & 18 & 43 & \\
\hline \multirow[t]{4}{*}{ Shenzhen } & & & & & & (Huang et al., 2020) \\
\hline & Formaldehyde & 13 & 20 & 52 & 15 & \\
\hline & Acetaldehyde & 10 & 35 & 47 & 8 & \\
\hline & Acetone & 14 & 20 & 30 & 36 & \\
\hline \multirow[t]{3}{*}{ Changdao Island } & & & & & & (Yuan et al., 2013) \\
\hline & Formic acid & 17.2 & 31.3 & - & 51.5 & \\
\hline & Acetic acid & 57.3 & 42.7 & - & 0 & \\
\hline
\end{tabular}


uted to the implementation of stricter emissions standards for new vehicles and specific control measures for in-use vehicles. However, studies also found that vehicle exhaust was the top source for $\mathrm{O}_{3}$ formation potential with a contribution of about $34.5 \%$ in cities such as Shenyang and Nanjing (Ma et al., 2019; Zhao et al., 2020). The strict controls on vehicle emissions should be process continuously through the PMF and the resulting emission trends suggest that their contributions have decreased in China. The main sources of solvent usage are pesticides and paint, in both industrial and architectural applications (Zheng et al., 2017), of which emissions have been increasing sharply, and may ultimately turn into the main source of NMVOCs in China in near future, especially in the developed regions with more industrial production. For example, Wang et al. (2014) found that solvent usage showed a significant increasing trend with a rate of $23.7 \% \mathrm{yr}^{-1}$ in Beijing. Processes using VOC-containing products are the main sources in industrial sections in China due to the rapid growth of industries and less effective emissions control measures; the amount of emissions related to industry presented an upward increasing trend in all reported inventories in China (Kurokawa et al., 2013; Wang et al., 2015; Li et al., 2017; Simayi et al., 2019). Zheng et al. (2017) predicted the future emissions of industrial sources in China under different scenarios and found that although the current increases are smaller than that of solvent usage, industrial emissions will significantly increase in 2020-50 in the absence of different policy implementations. The simulation results carried out by Sun et al. (2018b) further showed that industrial processes and solvent utilization are still the major contributors in 2020 and a reactivity-based control strategy should be taken to reduce NMVOCs emissions and their OFP.

Because of the inherent differences and limitations of receptor models and emission inventories, the source contribution results are not consistent, especially for solvent usage, LPG usage, and biogenic sources (Watson et al., 2001; Morino et al., 2011; Wang et al., 2014; Ou et al., 2018). According to our review, there are some gaps in current source emission inventories and receptor models that can be summarized as follows. First, uniform standards are lacking concerning the classification of VOC sources in the current emission inventory establishment, and some source profiles are replaced by the US EPA database, which may not exactly reflect the characteristics of VOCs in China (Liu et al., 2015a; Liang et al., 2017). Secondly, emission inventories solely focus on primary sources and there are non-existing categories for secondary formation or aging air masses in emission inventories. Thirdly, the reactivity of different VOC species might affect the results of receptor models, such as the chemical losses of highly reactive VOCs that would have the potential to change the source contributions resolved by PMF (Derwent et al., 2001; Belis et al., 2015), and the long-lived VOCs species might also be overestimated by PMF source appointment as they can accumulate in the atmosphere (de Gouw et al., 2005). To obtain accurate source appointment results, future work must be done in the areas of redeveloping emission inventories with high temporal and spatial resolution and confirming VOC source structures for receptor models and emission inventories.

\section{Conclusion and implications}

The total urban NMHCs have higher mixing ratios in the northwest, northeast, and developed cities of China compared to those in the central and southwest areas, while OVOCs have higher mixing ratios in the northwest and central areas as well as developed cities. Among all the NMVOCs, alkanes are the most abundant species followed by OVOCs. In recent years, NMHCs have been decreasing in the urban areas of Beijing and Shanghai, and the surrounding rural area of Guangzhou and Hong Kong. The seasonal concentrations of NMHCs are highest in winter while OVOCs are highest in summer. The diurnal variations of NMHCs characterized by higher mixing ratios in the morning and evening. While OVOCs showed a unimodal pattern with peaks around local noon.

As the key species of atmospheric oxidation capacity, research has revealed conclusive roles of both NMHCs and OVOCs in atmospheric photochemical reactions. However, due to the inherent complexity of photochemical reactions, many reaction processes and mechanisms have not be well understood, and some important reaction kinetics data are lacking. Further studies of atmospheric photochemical mechanisms are necessary for improving our understanding of atmospheric oxidation and oxidizing capacity. Study results on OFP showed that alkenes, aromatic hydrocarbons, and OVOCs are key activate species. Among all the NMVOCs, the contributions from the top eight species account for $50 \%-70 \%$ for OFP. Like OFP-NMHCs, OFP-OVOCs also make considerable contributions to $\mathrm{O}_{3}$ formation.

Vehicle exhaust, industrial emissions, and solvent usage are the main sources for NMHCs, while secondary formation is the major source for OVOCs. While emissions from vehicle exhausts have been decreasing, the emissions of solvent usage and industrial activities in China, especially in the developed regions, continue to increase. Therefore, placing controls upon solvent usage and industrial emissions in the country represents an effective strategy for emission reduction of NHMCs in the future. On the other hand, since vehicle exhaust contributes significantly to the main active NMVOCs, strict controls on vehicle emissions still remain necessary.

Acknowledgements. This work was financially supported by the National Key R\&D Plan programs (Grant No. 2017YFC0210005) and the National Natural Science Foundation of China (Grant No. 41773117).

\section{REFERENCES}

An, J. L., J. N. Zou, J. X. Wang, X. Lin, and B. Zhu, 2015: Differences in ozone photochemical characteristics between the 
megacity Nanjing and its suburban surroundings, Yangtze River Delta, China. Environmental Science and Pollution Research, 22(24), 19 607-19 617, https://doi.org/10.1007/ s11356-015-5177-0.

Atkinson, R., 2000: Atmospheric chemistry of VOCs and $\mathrm{NO}_{x}$ Atmos. Environ., 34(12-14), 2063-2101, https://doi.org/10. 1016/S1352-2310(99)00460-4.

Belis, C. A., D. Pernigotti, F. Karagulian, G. Pirovano, B. R. Larsen, M. Gerboles, and P. K. Hopke, 2015: A new methodology to assess the performance and uncertainty of source apportionment models in intercomparison exercises. Atmos. Environ., 119, 35-44, https://doi.org/10.1016/j.atmosenv. 2015.08.002.

Blanchard, C. L., 2003: Methods for attributing ambient air pollutants to emission sources. Annual Review of Energy and the Environment, 24, 329-365, https://doi.org/10.1146/annurev. energy.24.1.329.

Bo, Y., H. Cai, and S. D. Xie, 2008: Spatial and temporal variation of historical anthropogenic NMVOCs emission inventories in China. Atmospheric Chemistry and Physics, 8(23), 7297-7316, https://doi.org/10.5194/acp-8-7297-2008.

Cai, C. J., F. H. Geng, X. X. Tie, Q. Yu, and J. L. An, 2010: Characteristics and source apportionment of VOCs measured in Shanghai, China. Atmos. Environ., 44(38), 5005-5014, https://doi.org/10.1016/j.atmosenv.2010.07.059.

Chen, T. S., and Coauthors, 2020: Volatile organic compounds and ozone air pollution in an oil production region in northern China. Atmospheric Chemistry and Physics, 20(11), 7069-7086, https://doi.org/10.5194/acp-20-7069-2020.

Chen, W. T., M. Shao, S. H. Lu, M. Wang, L. M. Zeng, B. Yuan, and Y. Liu, 2014: Understanding primary and secondary sources of ambient carbonyl compounds in Beijing using the PMF model. Atmospheric Chemistry and Physics, 14(6), 3047-3062, https://doi.org/10.5194/acp-14-3047-2014.

Chi, Y. G., Z. Y. Li, Y. L. Feng, S. Wen, Z. Q. Yu, G. Y. Sheng, and J. M. Fu, 2008: Carbonyl compound concentrations in the air at Dinghu Mountain, Guangdong Province. Acta Scientiae Circumstantiae, 28(11), 2347-2353, https://doi.org/10. 3321/j.issn:0253-2468.2008.11.029. (in Chinese with English abstract)

de Gouw, J. A., and Coauthors, 2005: Budget of organic carbon in a polluted atmosphere: Results from the New England Air Quality Study in 2002. Journal of Geophysical Research, 110(D16), D16305, https://doi.org/10.1029/2004JD005623.

Deng, Y. Y., J. Li, Y. Q. Li, R. R. Wu, and S. D. Xie, 2019: Characteristics of volatile organic compounds, $\mathrm{NO}_{2}$, and effects on ozone formation at a site with high ozone level in Chengdu. Journal of Environmental Science, 75, 334-345, https://doi.org/10.1016/j.jes.2018.05.004.

Derwent, R. G., M. E. Jenkin, S. M. Saunders, and M. J. Pilling, 2001: Characterization of the reactivities of volatile organic compounds using a master chemical mechanism. Journal of the Air \& Waste Management Association, 51(5), 699-707, https://doi.org/10.1080/10473289.2001.10464297.

Du, W., A. Cohen, G. F. Shen, M. Y. Ru, H. Z. Shen, and S. Tao, 2018: Fuel use trends for boiling water in rural China (19922012) and environmental health implications: A national cross-sectional study. Environ. Sci. Technol., 52(21), 12 886-12 894, https://doi.org/10.1021/acs.est.8b02389.

Duan, J. C., J. H. Tan, L. Yang, S. Wu, and J. M. Hao, 2008: Concentration, sources and ozone formation potential of volatile organic compounds (VOCs) during ozone episode in
Beijing. Atmospheric Research, 88(1), 25-35, https://doi.org/ 10.1016/j.atmosres.2007.09.004.

Dunne, E., I. E. Galbally, M. Cheng, P. Selleck, S. B. Molloy, and S. J. Lawson, 2018: Comparison of VOC measurements made by PTR-MS, adsorbent tubes-GC-FID-MS and DNPH derivatization-HPLC during the Sydney Particle Study. 2012. A contribution to the assessment of uncertainty in routine atmospheric VOC measurements. Atmospheric Measurement Techniques, 11(1), 141-159, https://doi.org/10.5194/ amt-11-141-2018.

Fu, S., and Coauthors, 2020: Improving VOCs control strategies based on source characteristics and chemical reactivity in a typical coastal city of South China through measurement and emission inventory. Science of the Total Environment, 744, 140825, https://doi.org/10.1016/j.scitotenv.2020.140 825.

Gao, W., X. X. Tie, J. M. Xu, R. J. Huang, X. Q. Mao, G. Q. Zhou, and L. Y. Chang, 2017: Long-term trend of $\mathrm{O}_{3}$ in a mega City (Shanghai), China: Characteristics, causes, and interactions with precursors. Science of the Total Environment, 603-604, 425-433, https://doi.org/10.1016/j.scitotenv. 2017.06.099.

Gaudel, A., and Coauthors, 2018: Tropospheric Ozone Assessment Report: Present-day distribution and trends of tropospheric ozone relevant to climate and global atmospheric chemistry model evaluation. Elementa: Science of the Anthropocene, $\mathbf{6}(1), 39$, https://doi.org/10.1525/elementa.291.

Ge, S. S., and Coauthors, 2019: Abundant $\mathrm{NH}_{3}$ in China enhances atmospheric $\mathrm{HONO}$ production by promoting the heterogeneous reaction of $\mathrm{SO}_{2}$ with $\mathrm{NO}_{2}$. Environ. Sci. Technol., 53(24), 14 339-14 347, https://doi.org/10.1021/acs. est.9b04196.

Guo, H., T. Wang, D. R. Blake, I. J. Simpson, Y. H. Kwok, and Y. S. Li, 2006: Regional and local contributions to ambient non-methane volatile organic compounds at a polluted rural/coastal site in Pearl River Delta, China. Atmos. Environ., 40(13), 2345-2359, https://doi.org/10.1016/j. atmosenv.2005.12.011.

Guo, S. J., M. Chen, and J. H. Tan, 2016: Seasonal and diurnal characteristics of atmospheric carbonyls in Nanning, China. Atmospheric Research, 169, 46-53, https://doi.org/10.1016/ j.atmosres.2015.09.028.

Han, T. T., Z. Q. Ma, W. Y. Xu, L. Qiao, Y. R. Li, D. He, and Y. Wang, 2020: Characteristics and source implications of aromatic hydrocarbons at urban and background areas in Beijing, China. Science of the Total Environment, 707, 136083, https://doi.org/10.1016/j.scitotenv.2019.136083.

Hang, S., and Coauthors, 2008: Nitrous acid (HONO) and its daytime sources at a rural site during the 2004 PRIDE-PRD experiment in China. J. Geophys. Res., 113(D14), D14312, https://doi.org/10.1029/2007JD009060.

He, L., 2018: Pollution charaterization and source apportionment of vocs in Chengdu urban air. M.S. thesis, Southwest Jiaotong University. (in Chinese)

Ho, K. F., S. S. H. Ho, W. T. Dai, J. J. Cao, R.-J. Huang, L. W. Tian, and W. J. Deng, 2014: Seasonal variations of monocarbonyl and dicarbonyl in urban and sub-urban sites of Xi'an, China. Environmental Monitoring and Assessment, 186(5), 2835-2849, https://doi.org/10.1007/s10661-013-3584-6.

Huang, J., and Coauthors, 2008: Characteristics of carbonyl compounds in ambient air of Shanghai, China. Journal of Atmospheric Chemistry, 61(1), 1-20, https://doi.org/10.1007/ 
s10874-009-9121-X.

Huang, X.-F., B. Zhang, S.-Y. Xia, Y. Han, C. Wang, G.-H. Yu, and N. Feng, 2020: Sources of oxygenated volatile organic compounds (OVOCs) in urban atmospheres in North and South China. Environmental Pollution, 261, 114152, https://doi.org/10.1016/j.envpol.2020.114152.

Hui, L. R., and Coauthors, 2020: VOC characteristics, chemical reactivity and sources in urban Wuhan, central China. Atmos. Environ., 224, 117340, https://doi.org/10.1016/j. atmosenv.2020.117340.

Jia, C. H., 2018: Characteristics and chemical behaviors of atmospheric non-methane hydrocarbons in Lanzhou valley, Western China. PhD dissertation, Lanzhou University. (in Chinese)

Jia, C. H., and Coauthors, 2016: Non-methane hydrocarbons (NMHCs) and their contribution to ozone formation potential in a petrochemical industrialized city, Northwest China. Atmospheric Research, 169, 225-236, https://doi.org/10. 1016/j.atmosres.2015.10.006.

Kaser, L., and Coauthors, 2013: Comparison of different real time VOC measurement techniques in a ponderosa pine forest. Atmospheric Chemistry and Physics, 13(5), 2893-2906, https://doi.org/10.5194/acp-13-2893-2013.

Kurokawa, J., T. Ohara, T. Morikawa, S. Hanayama, J.-M. Greet, T. Fukui, K. Kawashima, and H. Akimoto, 2013: Emissions of air pollutants and greenhouse gases over Asian regions during 2000-2008: Regional Emission inventory in ASia (REAS) version 2. Atmospheric Chemistry and Physics Discussions, 13(4), 10 049-10 123, https://doi.org/10.5194/ acpd-13-10049-2013.

Le Breton, M., and Coauthors, 2018: Chlorine oxidation of VOCs at a semi-rural site in Beijing: Significant chlorine liberation from $\mathrm{ClNO}_{2}$ and subsequent gas- and particle-phase ClVOC production. Atmospheric Chemistry and Physics, 18(17), 13 013-13 030, https://doi.org/10.5194/acp-1813013-2018.

Li, B. W., and Coauthors, 2019a: Characterization of VOCs and their related atmospheric processes in a central Chinese city during severe ozone pollution periods. Atmospheric Chemistry and Physics, 19(1), 617-638, https://doi.org/10.5194/ acp-19-617-2019.

Li, J., S. D. Xie, L. M. Zeng, L. Y. Li, Y. Q. Li, and R. R. Wu, 2015: Characterization of ambient volatile organic compounds and their sources in Beijing, before, during, and after Asia-Pacific Economic Cooperation China 2014. Atmospheric Chemistry and Physics, 15(14), 7945-7959, https://doi.org/10.5194/acp-15-7945-2015.

Li, K., D. J. Jacob, H. Liao, L. Shen, Q. Zhang, and K. H. Bates, 2019b: Anthropogenic drivers of 2013-2017 trends in summer surface ozone in China. Proceedings of the National Academy of Sciences of the United State of America, 116(2), 422-427, https://doi.org/10.1073/pnas.1812168116.

Li, L., and Coauthors, 2020: Air quality changes during the COVID-19 lockdown over the Yangtze River Delta Region: An insight into the impact of human activity pattern changes on air pollution variation. Science of the Total Environment, 732, 139282, https://doi.org/10.1016/j.scitotenv.2020.139 282.

Li, L. F., and X. M. Wang, 2012: Seasonal and diurnal variations of atmospheric non-methane hydrocarbons in Guangzhou, China. International Journal of Environmental Research and Public Health, 9(5), 1859-1873, https://doi.org/10. 3390/ijerph9051859.

Li, M., and Coauthors, 2017: MIX: A mosaic Asian anthropogenic emission inventory under the international collaboration framework of the MICS-Asia and HTAP. Atmospheric Chemistry and Physics, 17(2), 935-963, https://doi.org/10. 5194/acp-17-935-2017.

Li, M., and Coauthors, 2019c: Persistent growth of anthropogenic non-methane volatile organic compound (NMVOC) emissions in China during 1990-2017: Drivers, speciation and ozone formation potential. Atmospheric Chemistry and Physics, 19(13), 8897-8913, https://doi.org/10.5194/acp-198897-2019.

Liang, X. M., X. F. Chen, J. N. Zhang, T. L. Shi, X. B. Sun, L. Y. Fan, L. M. Wang, and D. Q. Ye, 2017: Reactivity-based industrial volatile organic compounds emission inventory and its implications for ozone control strategies in China. Atmos. Environ., 162, 115-126, https://doi.org/10.1016/j.atmosenv. 2017.04.036.

Ling, Z. H., and H. Guo, 2014: Contribution of VOC sources to photochemical ozone formation and its control policy implication in Hong Kong. Environmental Science \& Policy, 38, 180-191, https://doi.org/10.1016/j.envsci.2013.12.004.

Liu, B. S., and Coauthors, 2016: Characterization and source apportionment of volatile organic compounds based on 1-year of observational data in Tianjin, China. Environmental Pollution, 218, 757-769, https://doi.org/10.1016/j.envpol.2016.07. 072.

Liu, H., H. Y. Man, M. Tschantz, Y. Wu, K. B. He, and J. M. Hao, 2015a: VOC from vehicular evaporation emissions: Status and control strategy. Environ. Sci. Technol., 49(24), 14 424-14 431, https://doi.org/10.1021/acs.est.5b04064.

Liu, S. C., M. Trainer, F. C. Fehsenfeld, D. D. Parrish, E. J. Williams, D. W. Fahey, G. Hübler, and P. C. Murphy, 1987: Ozone production in the rural troposphere and the implications for regional and global ozone distributions. J. Geophys. Res., 92(D4), 4191-4207, https://doi.org/10.1029/ JD092iD04p04191.

Liu, Y., M. Shao, W. C. Kuster, P. D. Goldan, X. H. Li, S. H. Lu, and J. A. de Gouw, 2009: Source identification of reactive hydrocarbons and oxygenated VOCs in the summertime in Beijing. Environ. Sci. Technol., 43(1), 75-81, https://doi.org/ 10.1021/es801716n

Liu, Y., and Coauthors, 2015b: Impact of pollution controls in Beijing on atmospheric oxygenated volatile organic compounds (OVOCs) during the 2008 Olympic Games: Observation and modeling implications. Atmospheric Chemistry and Physics, 15(6), 3045-3062, https://doi.org/10.5194/acp-153045-2015.

Louie, P. K. K., and Coauthors, 2013: VOCs and OVOCs distribution and control policy implications in Pearl River Delta region, China. Atmos. Environ., 76, 125-135, https://doi.org/ 10.1016/j.atmosenv.2012.08.058.

Lü, H. X., Q.-Y. Cai, S. Wen, Y. G. Chi, S. J. Guo, G. Y. Sheng, and J. M. Fu, 2010: Seasonal and diurnal variations of carbonyl compounds in the urban atmosphere of Guangzhou, China. Science of the Total Environment, 408(17), 3523-3529, https://doi.org/10.1016/j.scitotenv.2010.05.013.

Lyu, X. P., and Coauthors, 2020: Hazardous volatile organic compounds in ambient air of China. Chemosphere, 246, 125731, https://doi.org/10.1016/j.chemosphere.2019.125731.

Ma, Z. B., and Coauthors, 2019: The levels, sources and reactivity of volatile organic compounds in a typical urban area of 
Northeast China. Journal of Environmental Sciences, 79, 121-134, https://doi.org/10.1016/j.jes.2018.11.015.

Mellouki, A., T. J. Wallington, and J. Chen, 2015: Atmospheric chemistry of oxygenated volatile organic compounds: impacts on air quality and climate. Chemical Reviews, 115(10), 3984-4014, https://doi.org/10.1021/cr500549n.

Morino, Y., T. Ohara, Y. Yokouchi, and A. Ooki, 2011: Comprehensive source apportionment of volatile organic compounds using observational data, two receptor models, and an emission inventory in Tokyo metropolitan area. J. Geophys. Res., 116(D2), D02311, https://doi.org/10.1029/2010 JD014762.

Mozaffar, A., Y.-L. Zhang, M. Y. Fan, F. Cao, and Y.-C. Lin, 2020: Characteristics of summertime ambient VOCs and their contributions to $\mathrm{O}_{3}$ and SOA formation in a suburban area of Nanjing, China. Atmospheric Research, 240, 104923, https://doi.org/10.1016/j.atmosres.2020.104923.

Ou, J. M., J. Y. Zheng, Z. B. Yuan, D. B. Guan, Z. J. Huang, F. Yu, M. Shao, and P. K. K. Louie, 2018: Reconciling discrepancies in the source characterization of VOCs between emission inventories and receptor modeling. Science of the Total Environment, 628-629, 697-706, https://doi.org/10.1016/ j.scitotenv.2018.02.102.

Pang, X. B., and Y. J. Mu, 2006: Seasonal and diurnal variations of carbonyl compounds in Beijing ambient air. Atmos. Environ., 40(33), 6313-6320, https://doi.org/10.1016/j. atmosenv.2006.05.044.

Pang, X. B., and X. Q. Lee, 2010: Temporal variations of atmospheric carbonyls in urban ambient air and street canyons of a Mountainous city in Southwest China. Atmos. Environ., 44(17), 2098-2106, https://doi.org/10.1016/j.atmosenv.2010. 03.006.

Riedel, T. P., and Coauthors, 2014: An MCM modeling study of nitryl chloride $\left(\mathrm{ClNO}_{2}\right)$ impacts on oxidation, ozone production and nitrogen oxide partitioning in polluted continental outflow. Atmospheric Chemistry and Physics, 14(8), 3789-3800, https://doi.org/10.5194/acp-14-3789-2014.

Sahu, L. K., R. Yadav, and D. Pal, 2016: Source identification of VOCs at an urban site of western India: Effect of marathon events and anthropogenic emissions. J. Geophys. Res., 121(5), 2416-2433, https://doi.org/10.1002/2015JD024454.

Seinfeld, J. H., and S. N. Pandis, 2006: Atmospheric Chemistry and Physics: From Air Pollution to Climate Change. 2nd ed. John Wiley \& Sons, Inc., 429-443.

Sheng, J. J., D. L. Zhao, D. P. Ding, X. Li, M. Y. Huang, Y. Gao, J. N. Quan, and Q. Zhang, 2018: Characterizing the level, photochemical reactivity, emission, and source contribution of the volatile organic compounds based on PTR-TOF-MS during winter haze period in Beijing, China. Atmospheric Research, 212, 54-63, https://doi.org/10.1016/j.atmosres. 2018.05.005.

Shirley, T. R., and Coauthors, 2006: Atmospheric oxidation in the Mexico City Metropolitan Area (MCMA) during April 2003. Atmospheric Chemistry and Physics, 6, 2753-2765, https://doi.org/10.5194/acp-6-2753-2006.

Simayi, M., Y. F. Hao, J. Li, R. R. Wu, Y. Q. Shi, Z. Y. Xi, Y. Zhou, and S. D. Xie, 2019: Establishment of county-level emission inventory for industrial NMVOCs in China and spatial-temporal characteristics for 2010-2016. Atmos. Environ., 211, 194-203, https://doi.org/10.1016/j.atmosenv. 2019.04.064.

Su, Y. L., 2012: A preliminary study on the variation characterist- ics and reactivity of atmospheric VOCs in Urban area of Shanghai. M.S. thesis, East China University of Science and Technology.

Sun, J., Y. S. Wang, F. K. Wu, G. Q. Tang, L. L. Wang, Y. H. Wang, and Y. Yang, 2018a: Vertical characteristics of VOCs in the lower troposphere over the North China Plain during pollution periods. Environmental Pollution, 236, 907-915, https://doi.org/10.1016/j.envpol.2017.10.051.

Sun, W., M. Shao, C. Granier, Y. Liu, C. S. Ye, and J. Y. Zheng, 2018b: Long-term trends of anthropogenic $\mathrm{SO}_{2}, \mathrm{NO}_{x}, \mathrm{CO}$, and NMVOCs emissions in China. Earth's Future, 6(8), 1112-1133, https://doi.org/10.1029/2018EF000822.

Tang, X. Y., Y. H. Zhang, and M. Shao, 2006: Atmospheric Environmental Chemistry. 2nd ed., Higher Education Press, 739 pp. (in Chinese)

Tham, Y. J., and Coauthors, 2016: Significant concentrations of nitryl chloride sustained in the morning: Investigations of the causes and impacts on ozone production in a polluted region of northern China. Atmospheric Chemistry and Physics, 16(23), 14 959-14 977, https://doi.org/10.5194/acp-1614959-2016.

Thornton, J. A., and Coauthors, 2010: A large atomic chlorine source inferred from mid-continental reactive nitrogen chemistry. Nature, 464(7286), 271-274, https://doi.org/10.1038/ nature 08905.

Uchiyama, S., and S. Hasegawa, 2000: Investigation of a longterm sampling period for monitoring volatile organic compounds in ambient air. Environ. Sci. Technol., 34(21), 4656-4661, https://doi.org/10.1021/es990843u.

Volkamer, R., P. Sheehy, L. T. Molina, and M. J. Molina, 2010: Oxidative capacity of the Mexico City atmosphere-Part 1: A radical source perspective. Atmospheric Chemistry and Physics, 10(14), 6969-6991, https://doi.org/10.5194/acp-106969-2010.

Wang, G. H., and Coauthors, 2016a: Persistent sulfate formation from London Fog to Chinese haze. Proceedings of the National Academy of Sciences of the United States of America, 113(48), 1 3630-13 635, https://doi.org/10.1073/pnas. 1616540113.

Wang, M., and Coauthors, 2015: Trends of non-methane hydrocarbons (NMHC) emissions in Beijing during 2002-2013. Atmospheric Chemistry and Physics, 15(3), 1489-1502, https://doi.org/10.5194/acp-15-1489-2015.

Wang, M., M. Shao, W. Chen, B. Yuan, S. Lu, Q. Zhang, L. Zeng, and Q. Wang, 2014: A temporally and spatially resolved validation of emission inventories by measurements of ambient volatile organic compounds in Beijing, China. Atmospheric Chemistry and Physics, 14(12), 5871-5891, https://doi.org/10.5194/acp-14-5871-2014.

Wang, N., X. P. Lyu, X. J. Deng, X. Huang, F. Jiang, and A. J. Ding, 2019: Aggravating $\mathrm{O}_{3}$ pollution due to $\mathrm{NO}_{x}$ emission control in eastern China. Science of the Total Environment, 677, 732-744, https://doi.org/10.1016/j.scitotenv.2019.04. 388.

Wang, Q., 2020: Chemical characteristics and sources of volatile organic compounds in Shanghai during an ozone and particulate pollution episode in May 2019. Environmental Science, 41(6), 2555-2564, https://doi.org/10.13227/j.hjkx.20190 7115. (in Chinese with English abstract)

Wang, T., and Coauthors, 2016b: Observations of nitryl chloride and modeling its source and effect on ozone in the planetary boundary layer of southern China. J. Geophys. Res., 121(5), 
2476-2489, https://doi.org/10.1002/2015JD024556.

Wang, T., L. K. Xue, P. Brimblecombe, Y. F. Lam, L. Li, and L. Zhang, 2017a: Ozone pollution in China: A review of concentrations, meteorological influences, chemical precursors, and effects. Science of the Total Environment, 575, 1582-1596, https://doi.org/10.1016/j.scitotenv.2016.10.081.

Wang, Y., and Coauthors, 2017b: Long-term $\mathrm{O}_{3}$-precursor relationships in Hong Kong: Field observation and model simulation. Atmospheric Chemistry and Physics, 17(18), 10 919-10 935, https://doi.org/10.5194/acp-17-10919-2017.

Wang, Y. S., X. Y. Ren, D. S. Ji, J. Q. Zhang, J. Sun, and F. K. $\mathrm{Wu}, 2012$ : Characterization of volatile organic compounds in the urban area of Beijing from 2000 to 2007. Journal of Environmental Sciences, 24(1), 95-101, https://doi.org/10. 1016/S1001-0742(11)60732-8.

Warneke, C., T. Karl, H. Judmaier, A. Hansel, A. Jordan, W. Lindinger, and P. J. Crutzen, 1999: Acetone, methanol, and other partially oxidized volatile organic emissions from dead plant matter by abiological processes: Significance for atmospheric $\mathrm{HO}_{x}$ chemistry. Global Biogeochemical Cycles, 13(1), 9-17, https://doi.org/10.1029/98GB02428.

Watson, J. G., J. C. Chow, and E. M. Fujita, 2001: Review of volatile organic compound source apportionment by chemical mass balance. Atmos. Environ., 35(9), 1567-1584, https://doi.org/10.1016/S1352-2310(00)00461-1.

Wei, W., S. X. Wang, S. Chatani, Z. Klimont, J. Cofala, and J. M. Hao, 2008: Emission and speciation of non-methane volatile organic compounds from anthropogenic sources in China. Atmos. Environ., 42(20), 4976-4988, https://doi.org/ 10.1016/j.atmosenv.2008.02.044

Whalley, L. K., and Coauthors, 2009: The chemistry of OH and $\mathrm{HO}_{2}$ radicals in the boundary layer over the tropical Atlantic Ocean. Atmospheric Chemistry and Physics Discussions, 9(4), 15 959-16 009, https://doi.org/10.5194/acpd-9-159592009.

Wu, R. R., and S. D. Xie, 2017: Spatial distribution of ozone formation in China derived from emissions of speciated volatile organic compounds. Environ. Sci. Technol., 51(5), 2574-2583, https://doi.org/10.1021/acs.est.6b03634.

Wu, R. R., Y. Bo, J. Li, L. Y. Li, Y. Q. Li, and S. D. Xie, 2016a: Method to establish the emission inventory of anthropogenic volatile organic compounds in China and its application in the period 2008-2012. Atmos. Environ., 127, 244-254, https://doi.org/10.1016/j.atmosenv.2015.12.015.

Wu, R. R., J. Li, Y. F. Hao, Y. Q. Li, L. M. Zeng, and S. D. Xie, 2016b: Evolution process and sources of ambient volatile organic compounds during a severe haze event in Beijing, China. Science of the Total Environment, 560-561, 62-72, https://doi.org/10.1016/j.scitotenv.2016.04.030.

Xing, C. Z., and Coauthors, 2020: Identifying the wintertime sources of volatile organic compounds (VOCs) from MAXDOAS measured formaldehyde and glyoxal in Chongqing, southwest China. Science of the Total Environment, 715, 136258, https://doi.org/10.1016/j.scitotenv.2019.136258.

Xu, J. M., X. X. Tie, W. Gao, Y. F. Lin, and Q. Y. Fu, 2019: Measurement and model analyses of the ozone variation during 2006 to 2015 and its response to emission change in megacity Shanghai, China. Atmospheric Chemistry and Physics, 19(14), 9017-9035, https://doi.org/10.5194/acp-19-90172019.

Xu, Z. N., X. Huang, W. Nie, X. G. Chi, Z. Xu, L. F. Zheng, P. Sun, and A. J. Ding, 2017: Influence of synoptic condition and holiday effects on VOCs and ozone production in the Yangtze River Delta region, China. Atmos. Environ., 168, 112-124, https://doi.org/10.1016/j.atmosenv.2017.08.035.

Xue, L. K., and Coauthors, 2016: Oxidative capacity and radical chemistry in the polluted atmosphere of Hong Kong and Pearl River Delta region: Analysis of a severe photochemical smog episode. Atmospheric Chemistry and Physics, 16(15), 9891-9903, https://doi.org/10.5194/acp-16-98912016.

Xue, Y. G., Y. Huang, S. S. H. Ho, L. Chen, L. Q. Wang, S. C. Lee, and J. J. Cao, 2020: Origin and transformation of ambient volatile organic compounds during a dust-to-haze episode in northwest China. Atmospheric Chemistry and Physics, 20(9), 5425-5436, https://doi.org/10.5194/acp-20-54252020.

Yang, X., and Coauthors, 2018: Observations and explicit modeling of summertime carbonyl formation in Beijing: Identification of key precursor species and their impact on atmospheric oxidation chemistry. J. Geophys. Res., 123(2), 1426-1440, https://doi.org/10.1002/2017JD027403.

Yang, Y. C., X. G. Liu, J. Zheng, Q. W. Tan, M. Feng, Y. Qu, J. L. An, and N. L. Cheng, 2019a: Characteristics of one-year observation of VOCs, $\mathrm{NO}_{x}$, and $\mathrm{O}_{3}$ at an urban site in Wuhan, China. Journal of Environmental Sciences, 79, 297-310, https://doi.org/10.1016/j.jes.2018.12.002.

Yang, Z., H. R. Cheng, Z. W. Wang, J. Peng, J. X. Zhu, X. P. Lyu, and H. Guo, 2019b: Chemical characteristics of atmospheric carbonyl compounds and source identification of formaldehyde in Wuhan, Central China. Atmospheric Research, 228, 95-106, https://doi.org/10.1016/j.atmosres.2019.05 020 .

Yokelson, R. J., and Coauthors, 2009: Emissions from biomass burning in the Yucatan. Atmospheric Chemistry and Physics, 9(15), 5785-5812, https://doi.org/10.5194/acp-9-57852009.

Young, C. J., and Coauthors, 2012: Vertically resolved measurements of nighttime radical reservoirs in Los Angeles and their contribution to the urban radical budget. Environ. Sci. Technol., 46(20), 10 965-10 973, https://doi.org/10.1021/ es302206a.

Yuan, B., and Coauthors, 2012: Measurements of ambient hydrocarbons and carbonyls in the Pearl River Delta (PRD), China. Atmospheric Research, 116, 93-104, https://doi.org/ 10.1016/j.atmosres.2012.03.006.

Yuan, B., W. W. Hu, M. Shao, M. Wang, W. T. Chen, S. H. Lu, L. M. Zeng, and M. Hu, 2013: VOC emissions, evolutions and contributions to SOA formation at a receptor site in Eastern China. Atmospheric Chemistry and Physics, 13(3), 6631-6679, https://doi.org/10.5194/acp-13-8815-2013.

Yuan, B., A. R. Koss, C. Warneke, M. Coggon, K. Sekimoto, and J. A. de Gouw, 2017: Proton-transfer-reaction mass spectrometry: Applications in atmospheric sciences. Chemical Reviews, 117(21), 13 187-13229, https://doi.org/10.1021/acs. chemrev.7b00325.

Zhang, K., L. Li, L. Huang, Y. J. Wang, J. T. Huo, Y. S. Duan, Y. H. Wang, and Q. Y. Fu, 2020a: The impact of volatile organic compounds on ozone formation in the suburban area of Shanghai. Atmos. Environ., 232, 117511, https://doi.org/ 10.1016/j.atmosenv.2020.117511.

Zhang, L. H., and Coauthors, 2020b: Characteristics of atmospheric volatile organic compounds in urban area of Beijing: Variations, photochemical reactivity and source apportion- 
ment. Journal of Environmental Sciences, 95, 190-200, https://doi.org/10.1016/j.jes.2020.03.023.

Zhang, X. M., and Coauthors, 2017: Ambient volatile organic compounds pollution in China. Journal of Environmental Sciences, 55, 69-75, https://doi.org/10.1016/j.jes.2016.05.036.

Zhang, X. X., X. Ding, X. M. Wang, D. Talifu, G. Wang, Y. L. Zhang, and A. Abulizi, 2019: Volatile organic compounds in a petrochemical region in arid of NW China: Chemical reactivity and source apportionment. Atmosphere, 10(11), 641, https://doi.org/10.3390/atmos10110641.

Zhang, Y. L., and Coauthors,X. M. Wang, B. Barletta, I. J. Simpson, D. R. Blake, X. X. Fu, Z. Zhang, Q. F. He, T. Y. Liu, and X. Y. Zhao, 2013: Source attributions of hazardous aromatic hydrocarbons in urban, suburban and rural areas in the Pearl River Delta (PRD) region. Journal of Hazardous Materials, 250-251(2), 403-411, https://doi.org/10.1016/j. jhazmat.2013.02.023.

Zhang, Z., 2016: Spatiotemporal patterns of ambient non-methane hydrocarbons in China. PhD dissertation, Guangzhou Institute of Geochemistry, Chinese Academy of Sciences. (in Chinese)

Zhao, Q. Y., and Coauthors, 2020: Sources of volatile organic compounds and policy implications for regional ozone pollution control in an urban location of Nanjing, East China. Atmospheric Chemistry and Physics, 20(6), 3905-3919, https://doi.org/10.5194/acp-20-3905-2020.

Zheng, C. H., and Coauthors, 2017: Quantitative assessment of industrial VOC emissions in China: Historical trend, spatial distribution, uncertainties, and projection. Atmospheric Environment, 150, 116-125, https://doi.org/10.1016/j.atmosenv.
2016.11.023.

Zheng, J. Y., and Coauthors, Y. Yu, Z. Mo, Z. Zhang, X. Wang, S. Yin, K. Peng, Y. Yang, X. Feng, and H. Cai, 2013: Industrial sector-based volatile organic compound (VOC) source profiles measured in manufacturing facilities in the Pearl River Delta, China. Science of the Total Environment, 456457(7), 127-136, https://doi.org/10.1016/j.scitotenv.2013. 03.055 .

Zhou, M. M., W. Jiang, W. D. Gao, B. H. Zhou, and X. C. Liao, 2020: A high spatiotemporal resolution anthropogenic VOC emission inventory for Qingdao City in 2016 and its ozone formation potential analysis. Process Safety and Environmental Protection, 139, 147-160, https://doi.org/10.1016/ j.psep.2020.03.040.

Zhou, X., and Coauthors, 2019: Volatile organic compounds in a typical petrochemical industrialized valley city of northwest China based on high-resolution PTR-MS measurements: Characterization, sources and chemical effects. Science of the Total Environment, 671, 883-896, https://doi.org/10.1016/j. scitotenv.2019.03.283.

Zhu, J., S. S. Wang, H. L. Wang, S. G. Jing, S. R. Lou, A. SaizLopez, and B.Zhou, 2020: Observationally constrained modeling of atmospheric oxidation capacity and photochemical reactivity in Shanghai, China. Atmospheric Chemistry and Physics, 20(3), 1217-1232, https://doi.org/10.5194/acp-201217-2020.

Zou, Y., and Coauthors, 2015: Characteristics of 1 year of observational data of VOCs, $\mathrm{NO}_{x}$ and $\mathrm{O}_{3}$ at a suburban site in Guangzhou, China. Atmospheric Chemistry and Physics, 15(12), 6625-6636, https://doi.org/10.5194/acp-15-6625-2015. 